DOI: 10.32089/WBH.PHW.2021.2(276).0004

orcid.org/0000-0001-5856-7016

\author{
Artur OCHAE
}

Archiwum Straży Granicznej w Szczecinie

\title{
Dodatek graniczny i dodatki służbowe do uposażenia żołnierzy Korpusu Ochrony Pogranicza (1924-1939) $)^{1}$
}

\begin{abstract}
The Border Protection Corps (KOP) (1924-1939) was a special military formation to protect the eastern border of the Second Polish Republic. In terms of service and in terms of budget, KOP was subordinate to the Ministry of the Interior. In terms of wages, KOP soldiers were subject to the provisions of the Act on the remuneration of state officials and the army. Due to the specific nature of the service and to immunize the KOP soldiers against bribery by smugglers and Soviet agents, they were entitled to border allowances. The article discusses the principles of assigning service and functional allowances.

Jesienią 1924 r., dla ochrony przed bolszewicką dywersją i pospolitym bandytyzmem szerzącymi się na Kresach Wschodnich II Rzeczypospolitej Polskiej, na podstawie rozkazu ministra spraw wojskowych gen. Władysława Sikorskiego z 12 września 1924 r. utworzony został Korpus Ochrony Pogranicza (KOP). ${ }^{2}$ Korpus miał charakter specjalnej formacji wojskowej,

\footnotetext{
Pomysł artykułu poświęconego dodatkom dla żołnierzy KOP został poddany przez p. Macieja Gemrę, któremu autor bardzo dziękuje za inspirację i pomoc.

2 „Protokół z 88 posiedzenia Komitetu Politycznego Rady Ministrów, Warszawa, 8 VIII 1924," w O Niepodległa i granice. Korpus Ochrony Pogranicza 1924-1939. Wybór dokumentów, oprac. Marek Jabłonowski et al. (Warszawa-Pułtusk: Wyższa Szkoła Humanistyczna, Wydział Dziennikarstwa i Nauk Politycznych Uniwersytetu Warszawskiego, 2001), 16-18; „Z protokołu nr 89 Komitetu Politycznego Rady Ministrów poświęconego sprawie bezpieczeństwa na Kresach Wschodnich odbytego w obecności Prezydenta Rzeczypospolitej Stanisława Wojciechowskiego,” w ibid., 19-21; „Rozkaz ministra spraw wojskowych gen. dyw.
} 
której zadaniem była ochrona granicy wschodniej pod względem militarnym, politycznym, celno-skarbowym i sanitarnym. Utworzony został na bazie pułków piechoty i kawalerii Wojska Polskiego. W okresie służby pokojowej, w zakresie ochrony granicy, służby granicznej oraz finansowo podlegał Ministerstwu Spraw Wewnętrznych (MSW), natomiast pod względem personalnym, uzbrojenia i umundurowania, wyposażenia oraz zaopatrzenia zależny był od Ministerstwa Spraw Wojskowych (MSWojsk.). Od maja 1938 r. w sprawach wywiadu i przygotowań do zadań wojennych KOP podlegał również Generalnemu Inspektorowi Sił Zbrojnych (GISZ). W pierwszym okresie działalności, tj. od października 1924 r. do marca 1926 r., Korpus objął ochronę granicy polsko-radzieckiej, polsko-łotewskiej i polsko-litewskiej. Jesienią 1927 r. objął ochroną także fragmenty granic: polsko-niemieckiej z Prusami Wschodnimi oraz polsko-rumuńskiej wzdłuż Dniestru, natomiast w 1939 r. przejął także utworzoną granicę polsko-węgierską, a przekazał Straży Granicznej odcinek polsko-łotewski.

Do głównych zadań KOP należało m.in.: zabezpieczenie znaków i urządzeń granicznych przed celowym lub przypadkowym zniszczeniem, zabezpieczenie dochodów państwa $\mathrm{z}$ tytułu opłat celnych, zapobieganie nielegalnemu przekraczaniu granicy przez organy obce oraz przez osoby nieuprawnione, zapobieganie przenoszeniu antypolskich opracowań, ściganie wrogiej i antypaństwowej działalności, a także walka z rozprzestrzenianiem się chorób zakaźnych i ochrona granicy pod względem wojskowym w dziedzinie obronności państwa. W 1932 r. jednostki KOP ochraniały łącznie $2316,38 \mathrm{~km}$ granicy wschodniej, tj. 2/5 całej granicy II Rzeczypospolitej Polskiej. ${ }^{3}$ Według stanu na 1 stycznia 1931 r. służbę w KOP pełniło 732 oficerów i chorążych oraz 22545 podoficerów i szeregowych. ${ }^{4}$ Struktura KOP aż do wybuchu wojny w 1939 r. ulegała stopniowym przeobrażeniom, m.in. ze względu na zadania powierzone formacji w przypadku konfliktu zbrojnego oraz w związku ze zmianami sytuacji geopolitycznej w Europie.

W przekonaniu społeczeństwa II Rzeczypospolitej, ale także i wielu oficerów oraz podoficerów Wojska Polskiego, żołnierze służący w pododdziałach KOP w latach 1924-1939 byli dużo lepiej opłacani od pozostałych wojskowych,

Władysława Sikorskiego w sprawie organizacji KOP, Warszawa, 17 IX 1924 r.,” w ibid., 2141; „Instrukcja ministrów spraw wojskowych Władysława Sikorskiego oraz spraw wewnętrznych Cyryla Ratajskiego o przejęciu od armii oddziałów sformowanych dla KOP," w ibid., 41-46.

3 Oddziały KOP ochraniały w tym czasie: 1475,056 km granicy polsko-radzieckiej, 112,885 $\mathrm{km}$ polsko-łotewskiej, 539,812 km polsko-litewskiej, 75,7 km polsko-niemieckiej i 112,925 km polsko-rumuńskiej. Zob. Archiwum Straży Granicznej w Szczecinie (dalej: ASGran.), Dowództwo Korpusu Ochrony Pogranicza (dalej: Dowództwo KOP), sygn. 177/147, Komunikat dyslokacyjny KOP, Warszawa, 1932 r., 2-4.

4 „Stan etatowy KOP na dzień 1 I 1931 r.,” w O Niepodległa i granice, 208-214. 
a to za sprawą m.in. specjalnych dodatków wypłacanych im za służbę na granicy. ${ }^{5}$ Przeświadczenie to funkcjonuje także i dzisiaj, choć nikt nie prowadził kompleksowych badań i nie dokonywał porównań w tym zakresie. Pewne jest, że po 1926 r. status materialny kadry zawodowej WP stale wzrastał, początkowo za sprawą specjalnych dodatków służbowych, a następnie podwyżek, jakie miały miejsce m.in. w 1929 r. Z czasem uposażenie osób wojskowych stało się przedmiotem zazdrości nie tylko włościan, ale także i urzędników, szczególnie że wojskowi otrzymywali dodatkowe świadczenia, tj. dodatki dla rodzin, ulgi na przejazdy kolejowe, miejsca w sanatoriach i domach wypoczynkowych. Wysokie pensje oficerów i ich uprzywilejowana pozycja zaczęły drażnić społeczeństwo cywilne, które czuło się pomijane i lekceważone przez państwo polskie. ${ }^{6}$ Warto wspomnieć, że wprawdzie dziejom KOP poświęcono kilka obszernych publikacji i kilkanaście artykułów, ${ }^{7}$ ale w żadnym z nich nie poruszono kwestii uposażeń i dodatków przynależnych żołnierzom służącym $w$ tej formacji. $\mathrm{Z}$ tego też względu, $\mathrm{z}$ konieczności autor oparł swoje badania wyłącznie na dokumentach archiwalnych.

Przypomnieć należy, że Korpus Ochrony Pogranicza - jako specjalna formacja wojskowa MSW - w zakresie przepisów o uposażeniu żołnierzy podlegał zasadom określonym między innymi w:

- ustawie z 9 października 1923 r. o uposażeniu funkcjonariuszów państwowych i wojska (Dziennik Ustaw Rzeczypospolitej Polskiej 1923, nr 116 poz. 924$) ;^{8}$

- rozporządzeniu Prezydenta RP z 28 października 1933 r. o uposażeniu wojska (Dz.U.R.P. 1933, nr 86, poz. 664);

- obwieszczeniu ministra spraw wojskowych z 4 stycznia 1937 r. w sprawie ogłoszenia jednolitego tekstu rozporządzenia Prezydenta

\footnotetext{
5 Bogusław Bałos, List do autora, Kraków, 19 III 2007 r.; Jan Chojnacki, „Płocczanin Zdzisław Chojnacki 1900-1966," Warszawa 1997, mps w zbiorach autora.

6 Krótki rozdział pt. Status materialny znajdziemy w opracowaniu Piotra Staweckiego. Według przytoczonych przez niego obliczeń, w połowie lat trzydziestych XX w., roczna pensja oficera wynosiła $6774 \mathrm{zł}(564,5 \mathrm{zł}$ miesięcznie), podoficera zawodowego $3204 \mathrm{zł}$ (267 zł miesięcznie), a urzędników 2965 zł (247 zł miesięcznie). Zob. Piotr Stawecki, Z dziejów wojskowości Drugiej Rzeczypospolitej (Pułtusk: Wyższa Szkoła Humanistyczna, 2001), 293-295, 307-308.

7 Szerzej o KOP w opracowaniach: Henryk Dominiczak, Granica wschodnia Rzeczypospolitej Polskiej w latach 1919-1939 (Warszawa: Wyd. Naukowe PWN, 1992); Marek Jabłonowski, Formacja specjalna. Korpus Ochrony Pogranicza 1924-1939 (Warszawa: Ofic. Wyd. ASPRA-JR, 2002/2003); Artur Ochał, Tarcza II Rzeczypospolitej. Korpus Ochrony Pogranicza 1924-1939 (Warszawa: Wyd. Instytutu Pamięci Narodowej, 2018); Jerzy Prochwicz, Andrzej Konstankiewicz i Jan Rutkiewicz, Korpus Ochrony Pogranicza 1924-1939 (Warszawa: Barwa i Broń, 2003).

8 Artykuły prawne dotyczące osób wojkkowych (tj. 66-97) zostały zamieszczone w dziale „G” ustawy. Postanowienia ustawy zostały wprowadzone w wojsku „Dziennikiem Rozkazów MSWojsk.” (Dz. Roz. MSWojsk. 1924, nr 1).
} 
Rzeczypospolitej z dnia 28 października 1933 r. o uposażeniu wojska (Dz.U.R.P. 1937, nr 8, poz. 66);

- obwieszczeniu ministra spraw wojskowych z 17 maja 1938 r. w sprawie ogłoszenia jednolitego tekstu rozporządzenia Prezydenta Rzeczypospolitej z dnia 28 października 1933 r. o uposażeniu wojska (Dz.U.R.P. 1938, nr 43, poz. 362).

W powyższych aktach prawnych o charakterze ogólnym brak jest jednak odniesień szczegółowych dotyczących wyłącznie KOP, wskazujących podstawę prawną do przyznania poszczególnych dodatków w tej formacji, która uznawana była za integralną część Wojska Polskiego. Należy dodać, że zgodnie z interpretacją Ministerstwa Skarbu za osoby wojskowe uznawani byli wyłącznie żołnierze zawodowi oraz żołnierze rezerwy zatrzymani czasowo w czynnej służbie wojskowej. ${ }^{9}$ Tak przyjęte kryteria zawężały grupę osób wojskowych do oficerów i podoficerów zawodowych oraz rezerwistów w czynnej służbie nadterminowej, znaczy to, że do grupy tej nie zaliczano szeregowców obowiązkowej służby czynnej.

Celem niniejszego artykułu jest ustalenie i przypomnienie zasad przyznawania dodatków służbowych w ramach KOP. Podstawą do poniższych rozważań stał się Kalendarz informacyjny dla podoficerów zawodowych na rok 1939/40 znajdujący się w zasobie archiwalnym Archiwum Straży Granicznej w Szczecinie. ${ }^{10}$ Informator opracowany został przez ppłk. int. Józefa Mekszę, a wydany przez Główną Księgarnię Wojskową w 1939 r. W drugim rozdziale kalendarza pt. „Dodatki do uposażenia” opisane zostały rodzaje i zasady przyznawania dodatków do poborów podoficerów zawodowych (do chorążego włącznie), należy jednak uznać, że podobne zasady obowiązywały także w przypadku oficerów zawodowych. Ze względu na szeroki katalog wojskowych dodatków służbowych (w tym tzw. technicznych) w niniejszym studium odniesiono się wyłącznie do dodatków mających zastosowanie w KOP. W artykule wykorzystano dostępne dokumenty proweniencji KOP, w tym szczególnie rozkazy dowódców formacji oraz podległych im brygad i batalionów, odnoszące się do kwestii uposażeń i dodatków służbowych żołnierzy formacji. Ponadto autor sięgnął do wydanego w $1938 \mathrm{r}$. opracowania Uposażenia wojska oraz funkcjonariuszów państwowych i kontraktowych administracji wojskowej. Zbiór aktualnych przepisów uzupetniony wyczerpującymi objaśnieniami. Zbiór został opracowany przez Koło Oficerów

\footnotetext{
$9 \quad$ ASGran., Straż Graniczna 1928-1939, sygn. 187/264, Pismo Ministerstwa Skarbu do kancelarii cywilnej Prezydenta RP, biura Sejmu i Senatu, NIK, Prezydium Rady Ministrów i ministrów, Warszawa, 14 II 1930 r., 25-32.

10 Ibid., Dowództwo KOP, sygn. 177/496, „Kalendarz informacyjny dla podoficerów zawodowych zawierający informacje o: służbie, uposażeniu, sprawach emerytalnych, orderach i odznaczeniach", Warszawa, 1939 r., ss. 496.
} 
Intendentury.$^{11}$ Największym problemem dla autora okazał się niemal zupełny brak źródeł z pierwszych lat działalności KOP tj. okresu 1924-1928. Należy wspomnieć, że w trakcie badań wykorzystano m.in. zachowane listy płac dowództwa oraz batalionów KOP $z$ lat 1925-1939. Zdając sobie sprawę z zawiłości i zawikłań tematyki wojskowo-finansowej, tam, gdzie było to możliwe, autor podał przykłady sposobów naliczania uposażeń lub dodatków.

Wszyscy żołnierze zawodowi przydzieleni do KOP w okresie tworzenia tej formacji, tj. w drugim półroczu $1924 \mathrm{r}$. podlegali już przepisom tzw. „nowej ustawy” uposażeniowej tj. ustawy z 9 października 1923 r. o uposażeniu funkcjonariuszów państwowych i wojska (Dz.U.R.P. 1923, nr 116, poz. 924). ${ }^{12}$ Należy w tym miejscu przypomnieć, że uposażenie osób wojskowych złożone było $\mathrm{z}$ uposażenia zasadniczego oraz różnorakich dodatków oraz ekwiwalentów. Wysokość uposażenia zasadniczego naliczana była na podstawie wprowadzonej ustawą tabeli szczebli i grup uposażenia, do której przypisany był każdy wojskowy. Tabela określała punkty przypisane poszczególnym grupom uposażenia, a kwotę wynagrodzenia miesięcznego obliczano poprzez mnożenie punktów przez mnożną. Mnożna była zmienną wartością finansową ( $\mathrm{w}$ zł), zależną od możliwości budżetowych państwa. W pierwszych miesiącach działalności KOP mnożna uposażenia wahała się pomiędzy 0,41 zł w grudniu 1924 r. i maju 1925 r., 0,44 zł w listopadzie $1925 \mathrm{r}$. i $0,43 \mathrm{zł}$ w grudniu 1925 r. ${ }^{13}$ Oczywiście wysokość uposażenia zasadniczego miała decydujący wpływ na wysokość dodatków (w tym najważniejszego służbowego), które zazwyczaj obliczano procentowo. Należy pamiętać, że płace oficerów i żołnierzy zawodowych pełniących służbę $\mathrm{w}$ KOP podlegały opodatkowaniu zgodnie $\mathrm{z}$ art. 20 ustawy o państwowym podatku dochodowym. Przepisy o podatku wprowadzało rozporządzenie Ministra Skarbu z 30 kwietnia 1925 r. w sprawie tekstu ustawy o państwowym podatku dochodowym, w brzmieniu obowiązującem od czasu wejścia w życie ustawy z 18 marca 1925 r. (Dz.U.R.P. 1925, nr 58, poz. 411). Rozporządzenie ministra, na podstawie ustawy z 18 marca 1925 r. o państwowym podatku dochodowym (Dz.U.R.P. 1925, nr 36, poz. 242), określało, że za dochód uznawano uposażenie służbowe łącznie ze wszystkimi dodatkami,

11 Uposażenia wojska oraz funkcjonariuszów państwowych i kontraktowych administracji wojskowej. Zbiór aktualnych przepisów uzupełniony wyczerpujacymi objaśnieniami (Warszawa: Koło Oficerów Intendentów, 1938). Nie wszystkie przytoczone w tym opracowaniu uchwały Rady Ministrów i rozporządzenia ministrów udało się autorowi odnaleźć w dostępnych publikatorach aktów prawnych.

12 Ustawa została wprowadzona w życie z dniem 1 X 1923 r. Zarządzenie wykonawcze podano w Dz. Roz. MSWojsk. 1924, nr 1, poz. 9.

13 Mnożne zestawiono na podstawie rozkazów i list płac KOP z okresu 1924-1925. Zob. ASGran., Dowództwo KOP, sygn. 177/599, Listy płac Dowództwa KOP 1925-1931, ss. 436. 
także o charakterze jednorazowym, tj. dodatkiem na wyekwipowanie i remunerację (wyrównanie, rekompensatę) ${ }^{14}$ Podatek potrącany był przy obliczaniu należności przez płatników.

Wprowadzenie w 1933 r. nowych przepisów o uposażeniu wojska zmieniło także zasady naliczania uposażeń. Wprowadzono m.in. stałe tabele stawek uposażenia zasadniczego dla oficerów i podoficerów zawodowych, który zależny był nie tylko od stopnia, ale także od stanu rodzinnego i miejsca pełnienia służby - w stolicy lub w miejscowościach poza stolicą.

Tabela 1. Uposażenie zasadnicze żołnierzy zawodowych KOP (1934 r.)

\begin{tabular}{|l|c|c|}
\hline \multicolumn{2}{|c|}{ W miejscowościach poza stolicą } \\
\hline \multicolumn{1}{|c|}{ Stopień } & Samotni (zł) & Utrzymujący rodzinę (zł) \\
\hline Generał brygady & 1000 & 1000 \\
Pułkownik & 632 & 713 \\
Podpułkownik & 524 & 580 \\
Major & 435 & 490 \\
Kapitan (rotmistrz)a & 345 & 400 \\
Porucznik & 265 & 324 \\
Podporucznik & 206 & 266 \\
Chorąży & 230 & 300 \\
St. sierżant (równorzędny) & 194 & 264 \\
Sierżant (równorzędny) & 171 & 241 \\
Plutonowy (równorzędny) & 151 & 201 \\
Kapral (równorzędny) & 137 & 167 \\
\hline \multicolumn{2}{|c|}{ W stolicy } \\
Generał brygady & 1150 & 1150 \\
Pułkownik & 710 & 815 \\
Podpułkownik & 568 & 645 \\
Major & 485 & 560 \\
Kapitan (rotmistrz) & 390 & 465 \\
Porucznik & 290 & 365 \\
Podporucznik & 235 & 306 \\
Chorąży & 250 & 340 \\
St. sierżant (równorzędny) & 214 & 304 \\
Sierżant (równorzędny) & 190 & 276 \\
Plutonowy (równorzędny) & 170 & 236 \\
Kapral (równorzędny) & \multicolumn{2}{|c|}{} \\
\hline
\end{tabular}

a Od kwietnia 1938 r., oficerom zawodowym w stopniu kpt./rtm. lub kpt. marynarki wojennej po upływie pierwszych 9 lat służby zwiększano uposażenie o 45 zł. Ustawa z 9 IV 1938 r. zmieniała brzmienie art. 5 rozporządzenia Prezydenta RP z 28 X 1933 r., w którym dodano pkt. 2. Autorowi nie udało się znaleźć uzasadnienia tej zmiany. Zob. Ustawa o zmianie

14 Ibid., sygn. 177/11, Rozkaz nr 95, Warszawa, 15 IX 1925 r., 346. 
rozporządzenia prezydenta Rzeczypospolitej o uposażeniu wojska i marynarki wojennej (Dz.U. R.P. 1938, nr 26, poz. 231); Obwieszczenie ministra spraw wojskowych z 17 V 1938 r. w sprawie ogłoszenia jednolitego tekstu rozporządzenia Prezydenta Rzeczypospolitej z dnia 28 X 1933 r. o uposażeniu wojska i marynarki wojennej (Dz.U.R.P. 1938, nr 43, poz. 362).

b Zgodnie z art. 11 rozporządzenia z 28 X 1933 r., podchorążowie mianowani podporucznikami zawodowymi otrzymywali jednorazowy dodatek na wyekwipowanie w wysokości $850 \mathrm{zł}$ (w Marynarce Wojennej $970 \mathrm{zł}$ ). Oficerowie zawodowi po 2 latach od mianowania podporucznikami otrzymywali corocznie dodatek na uzupełnienie ekwipunku w wysokości $300 \mathrm{zl}$ (w marynarce 450 zł). Artykuł 11 został zmieniony 10 X 1936 r. dekretem Prezydenta RP. Nie określono w nim ustawowej wysokości kwoty dodatku na wyekwipowanie, lecz miał ją określić minister spraw wojskowych. Do treści artykułu dodano, że dodatek ten przysługiwał także zawodowym podoficerom przy mianowaniu chorążymi (równorzędnym). $Z$ dodatku potrącano koszty zużycia umundurowania otrzymanego w naturze za czas od mianowania. Utrzymana została wysokość dodatku po upływie 2 lat od mianowania tj. $300 \mathrm{zł} \mathrm{lub}$ 450 zł w marynarce. Zob. Rozporządzenie Prezydenta RP o uposażeniu wojska (Dz.U.R.P. 1933, nr 86, poz. 664); Dekret Prezydenta RP w sprawie zmiany rozporządzenia Prezydenta RP z dnia 28 X 1933 r. o uposażeniu wojska (Dz.U.R.P. 1936, nr 79, poz. 551).

Źródło: Rozporządzenie Prezydenta RP z 28 X 1933 r. o uposażeniu wojska i marynarki wojennej (Dz.U.R.P. 1933, nr 86, poz. 664).

Powyższe stawki uposażenia zostały utrzymane do momentu wybuchu wojny we wrześniu 1939 r. W tym miejscu warto podać przykłady uposażeń obliczanych na podstawie powyższego rozporządzenia. Według zachowanej listy płac za listopad 1938 r. gen. bryg. Janowi Kruszewskiemu, dowódcy KOP (grupa IV A) jako oficerowi pełniącemu służbę w Warszawie, naliczono należność w wysokości 2400 zł, w tym uposażenie zasadnicze $1150 \mathrm{zl}$, dodatek służbowy 1200 zł i 50 zł ekwiwalentu za usługi ordynansa. ${ }^{15}$ Potrącenia w wysokości 913,21 zł obejmowały: 587,5 zł podatek, 94 zł na fundusz zaliczek zwrotnych, 167,11 zł na fundusz kwaterunkowy, $6 \mathrm{zł}$ na opał, $10 \mathrm{zł}$ na oficerski Fundusz Pożyczkowo-Oszczędnościowy, 15 zł na Ligę Morską i Kolonialną, 15 zł na Fundusz Społeczny Żołnierzy KOP, 2 zł na Towarzystwo Wiedzy Wojskowej, 5 zł na Oficerskie Domy Wypoczynkowe, 50 zł na fundusz biblioteczny i 4 zł na utrzymanie Wojskowego Klubu Sportowego (WKS) „Legia”. Ostatecznie otrzymał do wypłaty 1486,79 zł. ${ }^{16}$ Ksiądz Stanisław Małek, dziekan KOP (grupa VI A) w Warszawie, miał naliczoną

15 Żołnierzom zawodowym (oficerom) przysługiwało prawo do korzystania z usług osobistego ordynansa, ale na mocy zarządzenia ministra mogło zostać zastąpione ekwiwalentem pieniężnym; zob. Dz. Roz. MSWojsk. 1934, nr 3, poz. 48.

16 Co ciekawe, wg listy płac z września 1933 r., pobory (wraz dodatkami) gen. Kruszewskiego wynosiły $1912,58 \mathrm{zł}$, a po potrąceniach wypłacono mu 1478,62 zł. Wynika z tego, że wraz ze wzrostem uposażenia w latach 1933-1938 znacząco zwiększyły się różnorakie obciążenia, a rzeczywiste wynagrodzenie pozostało na tym samym poziomie. Zob. ASGran., Dowództwo KOP, sygn. 177/602, Wykaz miesięczny uposażenia oficerów, podoficerów i pck dowództwa KOP za wrzesień 1933 r., Warszawa, 1933 r., 300-308; sygn. 177/607, Lista płac uposażenia oficerów i podoficerów Dowództwa KOP, Warszawa, listopad 1938 r., 671-677. 
należność w wysokości 805 zł, w tym 485 zł uposażenia zasadniczego, 270 zł dodatku służbowego i $50 \mathrm{zł}$ ekwiwalentu za ordynansa. Po potrąceniach wypłacono mu 644,28 zł. Jednym z najniżej uposażonych oficerów dowództwa KOP był por. Czesław Zaleski, płatnik (grupa VIII A), który miał naliczoną należność w wysokości 570 zł (w tym 155 zł dodatku służbowego). Po różnych potrąceniach wypłacono mu 434,09 zł. W przypadku podoficerów najlepiej uposażony był chor. Wincenty Niemczyk (grupa IX C), którego pobory wynosiły $388 \mathrm{zl}, \mathrm{w}$ tym $13 \mathrm{zł}$ dodatku wyrównawczego i $35 \mathrm{zl}$ dodatkowego. Po potrąceniach otrzymał on $285,22 \mathrm{zł}$. W tym samym czasie kpr. Aleksander Skorupa (grupa XII A) miał 165 zł uposażenia (w tym 13 zł dodatku służbowego), a po potrąceniach wypłacono mu 147,55 $\mathrm{zt}^{17}$

W maju 1939 r. płk Antoni Wandke, dowódca Pułku KOP „Wilno”, jako oficer pełniący służbę poza stolicą i utrzymujący rodzinę miał $1257 \mathrm{zł}$ uposażenia, w tym $713 \mathrm{zł}$ zasadniczego, $350 \mathrm{zł}$ dodatku służbowego, $154 \mathrm{zł}$ granicznego i 40 zł ekwiwalentu za ordynansa. Po potrąceniach łącznie 422,89 zł (w tym m.in. 3 zł na WKS „Śmigły”), wypłacono mu 834,11 zł. Kwatermistrz pułku kpt. Bronisław Krakowski, utrzymujący rodzinę, miał 400 zł płacy zasadniczej, 225 zł dodatku służbowego, 75 zł dodatku wyrównawczego, $86 \mathrm{zł} \mathrm{dodatku} \mathrm{granicznego} \mathrm{-} \mathrm{razem} 826 \mathrm{zł}$. Po potrąceniach $257,65 \mathrm{zł}$ (w tym 56,99 zł za kwaterę gminną) otrzymał 568,35 zł. ${ }^{18}$

\section{Dodatek wyrównawczy}

Po wprowadzeniu w 1923 r. ustawy o uposażeniach dla wojska, w związku ze zmianą zasad naliczania dotychczasowych dodatków służbowych, konieczne było wprowadzenie dodatku wyrównawczego przysługującego osobom wojskowym z tytułu zajmowania przed 1 października $1923 \mathrm{r}$. stanowisk wyższego stopnia, w przypadku zmiany stanowiska (zarówno w tym samym oddziale, jak i na skutek przeniesienia do innego), względnie w razie zmiany organizacji. Dodatek wyrównawczy przysługiwał do czasu pozostawania na etacie, który na danym stanowisku przewidywał stopień wyłącznie wyższy od posiadanego przez tego wojskowego. Żołnierze zawodowi (oficerowie i podoficerowie) przenoszeni służbowo (tak jak było to w przypadku KOP) mogli zatrzymać dodatek wyrównawczy, o ile w czasie przeniesienia pozostawali nadal na etacie wyższym od posiadanego stopnia. W tych przypadkach zatrzymywali prawo do dodatku wyrównawczego także po powrocie $\mathrm{z}$ przeniesienia na ten sam etat. $\mathrm{W}$ przypadku, gdy

17 Ibid., sygn. 177/607, Lista płac uposażenia oficerów i podoficerów Dowództwa KOP, Warszawa, listopad 1938 r., 671-677, 711-728.

18 Ibid., sygn. 177/627, Lista płac dowództwa Pułku KOP „Wilno”, Wilno, maj 1939 r., 1338-1340. 
żołnierze zawodowi w trakcie przeniesienia służbowego przestali zajmować etaty wyższe od posiadanego stopnia, automatycznie przestawali pobierać dodatek wyrównawczy. Po powrocie z przeniesienia na poprzednie stanowisko, na którym otrzymywali oni ten dodatek, nie mogli go ponownie pobierać, gdyż utracili do niego prawo w czasie przeniesienia służbowego. W formacjach nieewidencyjnych, posiadających składy osobowe, miarodajny był etat, na który zawodowi zostali zaliczeni w kadrze służby lub broni. Przykładowo, $\mathrm{z}$ tych względów oficerowie (porucznicy) zajmujący w jednym oddziale etaty wyłącznie wyższe od posiadanego stopnia (tj. etaty kapitanów), $\mathrm{w}$ razie przeniesienia do innego oddziału również na etaty wyższe (kapitanów), zatrzymywali prawo do dodatku wyrównawczego. Pobieranie dodatku wyrównawczego przysługiwało do momentu awansu lub przesunięcia do wyższego szczebla uposażenia, jednak pod warunkiem, że uposażenie to osiągnęło wysokość wcześniejszego uposażenia. Jeżeli na skutek awansu lub przesunięcia płaca nie osiągnęła tej wysokości, przysługiwał im nadal dodatek wyrównawczy, ale zmniejszony odpowiednio o różnicę liczby punktów uzyskanych po awansie lub przesunięciu. Przykładowo, porucznik szczebla „c" pobierał uposażenie 654 pkt., w tym 94 pkt. dodatku wyrównawczego. Jeżeli po awansie na kapitana otrzymał on prawo do uposażenia w szczeblu „a” w liczbie 600 pkt., to nadal przysługiwał mu dodatek wyrównawczy w wysokości 54 pkt. Jeżeli został przesunięty do szczebla „b” w stopniu kapitana, to tracił prawo do dodatku, gdyż suma punktów była wyższa od 654 pkt. Dodatek wyrównawczy można było także utracić na skutek zdjęcia $\mathrm{z}$ etatowego, wyższego stanowiska lub gdy etat ten uległ obniżeniu. Przy wprowadzeniu do organizacji wojska etatu ramowego (porucznik-kapi$\operatorname{tan)}$ w stosunku do porucznika na takim etacie, było to obniżenie etatu, $\mathrm{w}$ związku $\mathrm{z}$ tym tracił on prawo do dodatku wyrównawczego. $\mathrm{Z}$ dodatku przysługiwały mu jedynie punkty $\mathrm{w}$ chwili wejścia w życie ustawy uposażeniowej, odpowiednio do posiadanego faktycznego stopnia wojskowego i stanu rodzinnego. ${ }^{19}$

Należy wspomnieć, że na początku 1927 r. w związku z uzupełnieniem rządowego prowizorium budżetowego na łączny okres od 1 października $1926 \mathrm{r}$. do 31 marca 1927 r. miała miejsce $10 \%$ podwyżka uposażeń zasadniczych wszystkich oficerów i podoficerów zawodowych oraz oficerów rezerwy zatrzymanych w służbie czynnej, pełniących służbę wyłącznie na obszarze państwa polskiego. ${ }^{20}$ Podwyżka ta automatycznie miała wpływ na wysokość dodatków

19 Ibid., sygn. 177/12, Rozkaz dzienny KOP nr 56, Warszawa, 18 VI 1926 r., 196-197; sygn. 177/496, „Kalendarz informacyjny dla podoficerów zawodowych na rok 1939/40”, Warszawa, 1939 r., 168.

20 Podwyżka nie przysługiwała m.in. zawodowym osobom wojskowym pełniącym służbę na terenie Wolnego Miasta Gdańska oraz poza granicami kraju. Zob. Ustawa z dnia 18 XII 1926 r. 
tj. regulacyjnego, wyrównawczego, ekonomicznego, stołecznego i pogranicznego. ${ }^{21} \mathrm{Z}$ podwyżki tej zostali wyłączeni wojskowi pozostający na urlopach bezpłatnych, pobierający dodatek służbowy $z$ tytułu zajmowanego stanowiska, pozostający w stanie nieczynnym bez uposażenia, słuchacze szkół i kursów otrzymujący dodatek $\mathrm{z}$ tytułu przeniesienia służbowego. W przypadku słuchaczy otrzymujących stałą, comiesięczną zapomogę w wysokości 100 zł przysługiwała im podwyżka $10 \%$ z tym, że kwota tej podwyżki zmniejszała wypłacaną im zapomogę. Podwyżka obejmowała także podoficerów w służbie nadterminowej, którzy otrzymywali dodatek służbowy w wysokości połowy kwoty przysługującej samotnym kapralom zawodowym (tj. 7,31 zł). Podwyżka weszła $\mathrm{z}$ dniem 1 stycznia $1927 \mathrm{r}$. i podlegała normalnym zasadom naliczania podatku dochodowego i opłat emerytalnych. ${ }^{22}$

W marcu 1929 r. zgodnie z zarządzeniem Ministerstwa Skarbu wprowadzone zostały 15\% dodatki miesięczne, periodyczne, które wypłacane były od 1 maja. Dodatki wchodziły do ogólnej sumy uposażenia tylko przy obliczeniu wysokości opodatkowania, nie były jednak uwzględniane przy naliczeniu odpraw, odpraw pośmiertnych, zaliczek na uposażenie i ryczałtu na koszty przesiedlenia. Tym samym ten $15 \%$ dodatek nie miał wpływu na wysokość dodatków obliczanych na podstawie uposażenia, tj. pogranicznego (granicznego), technicznego itp. ${ }^{23} \mathrm{Z}$ treści rozkazu z lipca $1931 \mathrm{r}$. wynika, że od maja tego roku osobom wojskowym wypłacano $10 \%$ miesięczny dodatek do uposażenia. Wchodził on w skład uposażenia podlegającego opodatkowaniu. $^{24}$

Wraz ze zmianą przepisów uposażeniowych w 1933 r. zmieniły się także zasady wypłacania dodatku wyrównawczego, który zestawiony został w postaci tabeli, gdzie jego wysokość została uzależniona od stopnia wojskowego i szczebla uposażenia.

o uzupełnieniu prowizorjum budżetowego na czas od 1 X do 31 XII $1926 \mathrm{r}$. i o prowizorjum budżetowem na czas od 1 I do 31 III 1927 r. (Dz.U.R.P. 1926, nr 125, poz. 725); ASGran., Dowództwo KOP, sygn. 177/13, Rozkaz dzienny KOP nr 7, Warszawa, 21 I 1927 r., 21-22.

${ }^{21}$ Franciszek Kusiak wzmiankuje, że wzrost dodatków służbowych po przewrocie majowym w 1926 r. wyraźnie polepszył warunki bytowe kadry w stosunku do innych grup zawodowych w Polsce. Zob. Franciszek Kusiak, Życie codzienne oficerów drugiej Rzeczypospolitej (Warszawa: Państwowy Instytut Wydawniczy, 1992), 45-46.

22 ASGran., Dowództwo KOP, sygn. 177/13, Rozkaz dzienny KOP nr 7, Warszawa, 21 I 1927 r., 21-22; sygn. 177/14, Rozkaz nr 17, Warszawa, 27 II 1928 r., 53; Rozkaz nr 32, Warszawa, 28 III 1928 r., 102.

23 Jako podstawę rozkazu dziennego KOP podano: zarządzenie Ministerstwa Skarbu z 22 III 1929 r. nr D.III.671 oraz rozkaz intendentury ldz. KOP 885/29.Og.Int. z 25 IV 1929 r. Autorowi nie udało się odnaleźć publikacji powyższego zarządzenia Ministerstwa Skarbu. Zob. ibid., sygn. 177/15, Rozkaz nr 29, Warszawa, 31 V 1929 r., 141.

24 Ibid., sygn. 177/17, Rozkaz nr 31, Warszawa, 24 VII 1931 r., 195. 
Tabela 2. Wysokość dodatków wyrównawczych w KOP (od 1934 r. $)^{25}$

\begin{tabular}{|l|c|c|c|}
\hline \multirow{2}{*}{ Stopień } & \multicolumn{3}{|c|}{ Szczebel przed wejściem rozporządzenia } \\
\cline { 2 - 4 } & „b” & „c” & „d” \\
\cline { 2 - 4 } & - & 35 & 75 \\
Pułkownik & - & 30 & 60 \\
Modpułkownik & - & 30 & 60 \\
Kapitan (rotmistrz) & - & 25 & 50 \\
Porucznik & - & 20 & 35 \\
Podporucznik & 12 & 25 & 40 \\
Chorąży & - & 13 & 25 \\
St. sierżant (równorzędny) & - & 8 & 17 \\
Sierżant (równorzędny) & - & 8 & 16 \\
Plutonowy (równorzędny) & 6 & 13 & 19 \\
Kapral (równorzędny) & 6 & 12 & 19 \\
\hline
\end{tabular}

Źródło: Rozporządzenie Prezydenta RP z 28 X 1933 r. o uposażeniu wojska i marynarki wojennej (Dz.U.R.P. 1933, nr 86, poz. 664).

Dodatek wyrównawczy przysługiwał aż do najbliższego awansu (mianowania). Jeżeli po awansie okazało się, że należne uposażenie było niższe od ostatnio pobieranego wraz z dodatkiem wyrównawczym, awansowany zatrzymywał część dodatku, równą różnicy nowego uposażenia i poprzedniego. W ten sam sposób postępowano przy kolejnych awansach, aż do momentu wyrównania tych uposażeń. Dodatki wyrównawcze wypłacane były w tej wysokości do końca istnienia formacji tj. do wybuchu wojny we wrześniu 1939 r.

\section{Dodatek służbowy}

Najważniejszym rodzajem dodatku do uposażenia osób wojskowych był dodatek służbowy, będący comiesięczną należnością doliczaną do poborów, przysługującą żołnierzom zawodowym w służbie czynnej. Prawo do jego otrzymania powstawało $\mathrm{z}$ dniem mianowania oficerem lub podoficerem zawodowym, ${ }^{26}$ ewentualnie $\mathrm{z}$ dniem awansu, jeżeli mianowanie lub awans

\footnotetext{
25 Tabela została ograniczona do żołnierzy zawodowych KOP.

26 Ponadto dodatek służbowy przysługiwał oficerom rezerwy powołanym do służby czynnej celem przemianowania na zawodowych, a także oficerom i chorążym oraz podoficerom i szeregowym zawodowym w stanie spoczynku powołanym do służby czynnej w czasie wojny, mobilizacji lub w sytuacji zagrażającej bezpieczeństwu państwa. Zob. Uchwała Rady Ministrów z 26 III 1934 r. w sprawie dodatków służbowych dla żołnierzy wojska i marynarki wojennej (Dz. Roz. MSWojsk. 1934, nr 4 poz. 54); Archiwum Akt Nowych w Warszawie (dalej: AAN), Prezydium Rady Ministrów (1917-1939) (dalej: PRM), sygn. 2/8/0/1.2/I.73, Załącznik nr 1 do protokołu PRM z 26 III 1934 r., Warszawa, 216-218.
} 
nastąpił z pierwszym dniem miesiąca kalendarzowego. $\mathrm{W}$ innych przypadkach naliczany był od pierwszego dnia najbliższego miesiąca kalendarzowego po dniu mianowania lub awansu. Podstawą do zaszeregowania było ogłoszenie podane w rozkazie wewnętrznym (dziennym) danego oddziału, w którym mianowany lub awansowany pełnił służbę. ${ }^{27}$

Dodatek przysługiwał żołnierzom zawodowym na etatowych stanowiskach służbowych od sierżanta-szefa i dowódcy plutonu wzwyż bez względu na posiadany stopień wojskowy. Dodatek był wypłacany „z góry” wraz $\mathrm{z}$ uposażeniem zasadniczym wynikającym $\mathrm{z}$ tabeli zaszeregowania. Wymiar dodatku nie podlegał procentowemu zwiększeniu z tytułu otrzymywania dodatku stołecznego lub pogranicznego. Dodatek służbowy nie wpływał na wymiar odpraw przysługujących $\mathrm{z}$ racji zwolnienia ze służby lub odprawy pośmiertnej. Nie mógł być także doliczany do poborów w celu obliczenia kosztów przesiedlenia. Od dodatku potrącany był podatek dochodowy, natomiast nie podlegał on opłatom emerytalnym. ${ }^{28}$

W tym miejscu dla przykładu można podać wysokość uposażenia wybranych oficerów KOP. Według listy płac Dowództwa KOP z października 1925 r. ${ }^{29}$ gen. dyw. Henrykowi Minkiewiczowi naliczono 1904 pkt. uposażenia, na które składały się punkty za: stopień wojskowy, grupę i szczebel uposażenia (III „A" - 1200 pkt.), stan rodzinny (żona), co po przeliczeniu wg mnożnej 0,43 zł wyniosło 818,72 zł. Do tej kwoty dochodził 20\% dodatek stołeczny, tj. 163,74 zł i dodatek mieszkaniowy 114,14 zł. Po łącznych potrąceniach 143,74 zł (m.in. 3\% na emeryturę), dowódca formacji pokwitował odbiór 952,86 zł uposażenia. Ponadto, jako dowódcy formacji, przysługiwało mu 800 pkt. dodatku reprezentacyjnego (tj. 344 zł). Zastępca dowódcy gen. bryg. Józef Tokarzewski (grupa IV „A”) otrzymał w tym miesiącu 724,28 zł. Natomiast najniżej uposażony oficer dowództwa - por. Rudolf Geyer (grupa VIII „C”), kawaler - miał 620 pkt., tj. 266,6 zł uposażenia zasadniczego, do tego 53,32 zł dodatku stołecznego i 9,62 zł mieszkaniowego. Po potrąceniach $(35,62 \mathrm{zł})$ otrzymał 293,92 zł pensji. Sierżant Stefan Setkowicz, samotny podoficer pełniący służbę w Dowództwie KOP

\footnotetext{
27 ASGran., Dowództwo KOP, sygn. 177/12, Rozkaz dzienny KOP nr 104, Warszawa, 7 XII 1926 r., 367; sygn. 177/15, Rozkaz nr 30, Warszawa, 5 VI 1929 r., 147.

28 Od 1 VIII 1926 r. obowiązywała uchwała Rady Ministrów z 5 VIII 1926 r. w sprawie przyznania osobom wojskowym dodatków służbowych. Zob. ibid., sygn. 177/12, Rozkaz dzienny KOP nr 77, Warszawa, 20 VIII 1926 r., 253-255; Rozkaz nr 113, Warszawa, 24 XII 1926 r., 415; sygn. 177/13, Rozkaz dzienny KOP nr 22, Warszawa, 25 II 1927 r., 107; sygn. 177/16, Rozkaz nr 22, Warszawa, 15 V 1930 r., 146; Dodatki służbowe (Dz. Roz. MSWojsk. 1926, nr 21, poz. 225, 149-156); Dodatki służbowe - zmiana rozporządzenia wykonawczego (Dz. Roz. MSWojsk. 1927, nr 8, poz. 70, 138-145).
}

29 Wcześniejsze listy płac dowództwa KOP nie zachowały się. 
(grupa XI „B”), miał 350 pkt tj. 150,5 zł uposażenia zasadniczego, ale wraz $\mathrm{z}$ dodatkami i po potrąceniach otrzymał $170,95 \mathrm{zt}^{30}$

Tabela 3. Zaszeregowanie oficerów i podoficerów zawodowych KOP na podstawie rozporządzenia MSWojsk. z 7 sierpnia $1926 \mathrm{r}$.

\begin{tabular}{|l|c|l|c|}
\hline Kategoria & $\begin{array}{c}\text { Liczba } \\
\text { punktów } \\
\text { (uposażenie } \\
\text { zasadnicze) }\end{array}$ & \multicolumn{1}{|c|}{ Stanowiska w KOP } & $\begin{array}{c}\text { Przeliczenie } \\
\text { wg mnożnej } \\
\mathbf{0 , 4 3} \text { zł }\end{array}$ \\
\hline III A & 1200 & dowódca KOP & 516,0 \\
\hline IV B & 800 & zastępca dowódcy KOP & 344,0 \\
\hline V & 700 & $\begin{array}{l}\text { szef Sztabu KOP, szef Intendentury KOP, } \\
\text { dowódcy brygad KOP }\end{array}$ & 301,0 \\
\hline VI B & 500 & $\begin{array}{l}\text { szefowie oddziałów KOP, kierownicy samodzielnych } \\
\text { referatów Dowództwa KOP na stanowiskach } \\
\text { oficerów sztabowych, dowódcy batalionów KOP, } \\
\text { zastępcy szefów w Dowództwie KOP }\end{array}$ & 215,0 \\
\hline VII B & $\begin{array}{l}\text { kierownicy referatów Sztabu KOP, kierownicy } \\
\text { referatów Szefostwa Służby KOP, kierownik } \\
\text { Wydziału Budżetowo-Rachunkowego KOP, } \\
\text { I oficerowie sztabu w dowództwach brygad } \\
\text { KOP, dowódcy szwadronów, lekarze weterynarii } \\
\text { w dowództwach brygad, kierownicy służby } \\
\text { intendentury w dowództwach brygad, kapelani } \\
\text { w dowództwach brygad }\end{array}$ & 129,0 \\
\hline VIII & $\begin{array}{l}\text { dowódcy kompanii, referenci w Sztabie } \\
\text { Dowództwa KOP, referenci w Szefostwie } \\
\text { Służby Dowództwa KOP, referenci w Wydziale } \\
\text { Budżetowo-Rachunkowym Dowództwa KOP, } \\
\text { oficer ordynansowy dowódcy KOP, II oficerowie } \\
\text { sztabu w dowództwach brygad, oficerowie } \\
\text { administracyjni w dowództwach brygad, referenci } \\
\text { służby uzbrojenia w dowództwach brygad, } \\
\text { referenci służby łączności w dowództwach } \\
\text { brygad, adiutanci batalionów, kwatermistrzowie } \\
\text { batalionówa , płatnicy batalionów, oficerowie } \\
\text { materiałowi batalionów, lekarze batalionów }, \\
\text { dowódcy plutonów łączności batalionów, } \\
\text { dowódcy kompanii szkolnych w brygadach, } \\
\text { oficerowie ordynansowi dowódców brygad }\end{array}$ & 107,5 \\
\hline
\end{tabular}

30 Generał bryg. Józef Tokarzewski miał na utrzymaniu żonę i dziecko. Według danych statystycznych za 1925 r. przeciętne koszty utrzymania w Warszawie wynosiły 149,4 zł. Wydatki na żywność przeciętnie 176,1 zł, na odzież i obuwie 197,4 zł, na opał 157,4 zł i na mieszkanie 56,7 zł. Zob. ASGran., Dowództwo KOP, sygn. 177/599, Lista płac za październik 1925 r., Warszawa b.d., 2-5; Rocznik statystyki Rzeczypospolitej Polskiej (Warszawa: GUS, 1927), 239. 


\begin{tabular}{|l|c|l|c|}
\hline IX & 150 & $\begin{array}{l}\text { dowódcy plutonów (oficerowie młodsi) } \\
\text { w batalionach lub szwadronach, kierownik } \\
\text { kancelarii w Dowództwie KOP, oficerowie } \\
\text { kancelaryjni Dowództwa KOP, oficerowie } \\
\text { żywnościowi batalionów, oficerowie młodsi } \\
\text { i chorążowie na stanowiskach por./ppor. } \\
\text { niewymienieni w innych pozycjach }\end{array}$ & 64,5 \\
\hline $\mathrm{X}$ & 50 & $\begin{array}{l}\text { sierżanci - szefowie kompanii, wachmistrzowie } \\
\text { - szefowie szwadronów, podoficerowie } \\
\text { zawodowi pełniący obowiązki dowódców } \\
\text { plutonów, podoficerowie zawodowi na etatowych } \\
\text { stanowiskach oficerów młodszych; wachmistrz - } \\
\text { szef oddziału sztabowego KOP }\end{array}$ & 21,5 \\
\hline
\end{tabular}

a Na podstawie Dz. Roz. MSWojsk. 1927, nr 3, poz. 34, od 1 I 1928 r. zaszeregowani byli w kategorii VII B tj. 300 pkt. Zob. ASGran., Dowództwo KOP, sygn. 177/14, Rozkaz nr 17, Warszawa, 27 II 1928 r., 53.

b Zgodnie z wyjaśnieniem dowódcy KOP z 24 XII 1926 r., lekarze w batalionach pełnili funkcje samodzielnie i byli jedynymi lekarzami w tych jednostkach, dlatego przysługiwał im dodatek służbowy wg kategorii VII B tj. 300 pkt. Zob. ibid., sygn. 177/12, Rozkaz dzienny KOP nr 113, Warszawa, 24 XII 1926 r., 415.

Źródło: ASGran., Dowództwo KOP, sygn. 177/12, Rozkaz dzienny KOP nr 77, Warszawa, 20 VIII 1926 r., 253-255; Rozkaz nr 98, Warszawa, 20 XI 1926 r., 338-341.

W przypadku zaszeregowania oficerów na niektórych stanowiskach, określonych jako „stanowisko oficera sztabowego” lub „stanowisko oficera młodszego", wymiar ich dodatku służbowego zależny był od tego, czy skład osobowy oddziału przewidywał na to stanowisko oficera sztabowego (od majora do pułkownika) lub oficera młodszego (od podporucznika do kapitana). W przypadku, gdy w zaszeregowaniu przy stanowisku znajdowało się dookreślenie „o ile jest oficerem sztabowym”, względnie „o ile jest oficerem młodszym”, wysokość dodatku służbowego zależała od posiadanego stopnia oficerskiego. Dodatek przysługiwał także oficerom rezerwy zatrzymanym w służbie czynnej w wysokości określonej dla zajmowanego przez nich stanowiska. Chorążowie pełniący służbę na stanowiskach oficerskich otrzymywali dodatek służbowy w wymiarze przewidzianym dla tego stanowiska od pierwszego dnia najbliższego miesiąca kalendarzowego rozpoczynającego się po dniu objęcia stanowiska. Chorążowie zasadniczo mogli być wyznaczani na stanowiska podporuczników lub poruczników zaszeregowanych do IX kategorii, jednak wyjątkowo, gdy zajmowali wyższe stanowiska, otrzymywali dodatek wyższej kategorii. ${ }^{31}$ Chorążowie na stanowiskach

31 Przykładowo, dowódca KOP w 1929 r. przyznał chor. Wincentemu Niemczykowi dodatek służbowy wg VIII grupy zaszeregowania za czas pełnienia przez niego obowiązków oficera administracyjnego dowództwa 1 Brygady KOP. Zob. ASGran., Dowództwo KOP, sygn. 177/15, Rozkaz nr 7, Warszawa, 6 II 1929 r., 27. 
podoficerskich, jeżeli były one zaliczone do kategorii X, otrzymywali dodatek w tej kategorii. Chorążym, którzy pełnili służbę na etatowych stanowiskach urzędników cywilnych z powodu przeprowadzonej ich redukcji, nie przysługiwał dodatek służbowy do czasu zamiany na stanowiska wojskowe przewidziane $\mathrm{w}$ zaszeregowaniu. Podoficerowie zawodowi bez względu na posiadany stopień wojskowy, jeżeli zajmowali stanowiska etatowe nieprzewidziane $\mathrm{w}$ zaszeregowaniu dla $\mathrm{X}$ kategorii (m.in. personel kancelaryjny lub magazynierzy), nie mieli prawa do otrzymywania dodatku służbowego. ${ }^{32}$ Specjalny dodatek służbowy przysługiwał podoficerom zawodowym zajmującym etatowe stanowiska sierżanta-szefa. Dodatek wprowadzony został w 1924 r. na podstawie uchwały Rady Ministrów. ${ }^{33}$ Przysługiwał on podoficerom, którym powierzono zadanie prowadzenie służby wewnętrznej w kompaniach lub szwadronach KOP, na etatowych stanowiskach sierżantów-szefów, bez względu na posiadany przez nich stopień wojskowy. Zgodnie $\mathrm{z}$ rozporządzeniem wykonawczym z $1924 \mathrm{r}$. podoficerom na tych stanowiskach przysługiwał dodatek miesięczny $\mathrm{w}$ wysokości 6 punktów (tj. 2,462,58 zł) w oddziałach o liczebności ponad 100 żołnierzy lub 3 punktów (tj. 1,23-1,29 zł) w oddziałach mniejszych. Dodatek wypłacany był miesięcznie „Z góry”, a prawo do jego otrzymania przysługiwało z pierwszym dniem miesiąca po objęciu stanowiska, a traciło z ostatnim dniem miesiąca, w którym podoficer je opuścił. Podoficerowie nieobsadzeni na etatach szefów kompanii lub szwadronów, lecz przykładowo $\mathrm{w}$ administracji, magazynach lub w kancelariach, ale wykonujący obowiązki szefów, nie mieli prawa do tego dodatku. ${ }^{34}$

Dodatek służbowy nie przysługiwał osobom wojskowym pozostającym bez przydziału służbowego, będącym pod dochodzeniem sądowym lub dyscyplinarnym, jeżeli zostały one zawieszone w czynnościach służbowych, pozostającym na urlopie ponad czas ustawowy, a także osobom, które dwukrotnie otrzymały ujemną roczną kwalifikację zawodową. Ponadto dodatku nie otrzymywały osoby w stanie nieczynnym, na urlopach bez uposażenia i w stanie spoczynku. ${ }^{35}$

32 Ibid., sygn. 177/12, Rozkaz dzienny KOP nr 100, Warszawa, 27 XI 1926 r., 356-357; Rozkaz dzienny KOP nr 109, Warszawa, 18 XII 1926 r., 388-389.

33 Uchwała Rady Ministrów z 21 I 1924 r. w sprawie dodatku dla sierżanta szefa. Zob. Dz. Roz. MSWojsk. 1924, nr 17, poz. 270, 313-320.

34 Dz. Roz. MSWojsk. 1924, nr 17, poz. 270, 313-320; Dodatki służbowe - zmiana rozporządzenia wykonawczego (Dz. Roz. MSWojsk. 1927, nr 8, poz. 70, 138-145); ASGran., Dowództwo KOP, sygn. 177/12, Rozkaz dzienny KOP nr 94, Warszawa, 28 X 1926 r., 324; Rozkaz nr 100, Warszawa, 27 XI 1926 r., 356.

35 ASGran., Dowództwo KOP, sygn. 177/12, Rozkaz nr 77, Warszawa, 20 VIII 1926 r., 253-255. 
Zgodnie z obowiązującą od 1 stycznia 1927 r. nowelizacją rozporządzenia wykonawczego do uchwały Rady Ministrów z 5 sierpnia 1926 r. w sprawie przyznania osobom wojskowym dodatków służbowych ${ }^{36}$ zasadniczo oficerowie niezajmujący stanowisk etatowych nie mieli prawa do dodatku służbowego. Jednakże w przypadku oficerów, którzy pełnili służbę na stanowiskach, które organizacyjnie nie zostały przewidziane przez ustawodawcę i nie zostali wyłączeni z prawa do dodatku, dowódca KOP mógł przyznać dodatek na podstawie umotywowanego wniosku władzy przełożonej. Natomiast $\mathrm{w}$ przypadku oficerów odbywających praktykę poborową ${ }^{37}$ przysługi- $^{-}$ wał dodatek według kategorii VII, oficerom młodszym w kategorii VIII. ${ }^{38}$

Żołnierze zawodowi niepełniący służby z powodu choroby lub urlopu zdrowotnego zachowywali dodatek służbowy przez sześć miesięcy, licząc od pierwszego dnia miesiąca, następnego po zaprzestaniu pełnienia obowiązków z powodu choroby. Po ustaniu ww. przyczyn, tj. po ponownym objęciu służby, po prawomocnym uwolnieniu od oskarżeń lub przywróceniu z dyspozycji, dodatek był im przywracany. Należy wspomnieć, że uwolnienie od oskarżenia nie powodowało wypłaty dodatku służbowego za czas, w którym nie był on pobierany $\mathrm{z}$ powodu zawieszenia $\mathrm{w}$ czynnościach służbowych. ${ }^{39}$

Oficerom lub podoficerom zawodowym, którzy $\mathrm{z}$ powodu choroby względnie urlopu dla poratowania zdrowia nie pełnili służby $\mathrm{w}$ dniu 1 sierpnia $1926 \mathrm{r}$. (data wprowadzenia rozporządzenia o dodatkach służbowych) przysługiwał dodatek służbowy od ww. daty do końca zwolnienia lub urlopu zdrowotnego, jednak maksymalnie do sześciu miesięcy, w wysokości należnej zajmowanemu stanowisku przed chorobą lub urlopem. Jeżeli choroba bądź urlop zdrowotny przeciągnęła się ponad sześć miesięcy, dodatek służbowy im nie przysługiwał. ${ }^{40}$

Z treści wyjaśnienia podanego w rozkazie KOP z 1926 r. wynika, że dodatek służbowy w tym okresie nie przysługiwał także podczas długotrwałego

36 Jako podstawę prawną rozkazu KOP podano rozporządzenie MSWojsk. Dep. VII Int. Ldz.500/27.Wydz.Up. z 18 II 1927 r. Również w dzienniku rozkazów MSWojsk. podano jako podstawę D. VII 500 UP. Autorowi nie udało się odnaleźć opublikowanej uchwały Rady Ministrów z 5 VIII 1926 r. Zob. ibid, sygn. 177/13, Rozkaz dzienny KOP nr 32, Warszawa, 21 III 1927 r., 149-152; Dz. Roz. MSWojsk. 1927, nr 8, poz. 70, 138-145.

37 Praktyka odbywana przez oddelegowanych oficerów w komendach uzupełnień w zakresie przygotowania i przeprowadzenia poboru oraz prowadzenia ewidencji i administracji rezerw.

38 ASGran., Dowództwo KOP, sygn. 177/496, „Kalendarz informacyjny dla podoficerów zawodowych na rok 1939/40", Warszawa, 1939 r., 170-171; Dodatki służbowe - zmiana rozporządzenia wykonawczego (Dz. Roz. MSWojsk. 1927, nr 8, poz. 70, 138-145).

39 ASGran., Dowództwo KOP, sygn. 177/13, Rozkaz dzienny KOP nr 32, Warszawa, 21 III 1927 r., $149-152$.

40 Ibid., sygn. 177/12, Rozkaz dzienny KOP nr 87, Warszawa, 1 X 1926 r., 292; sygn. 177/13, Rozkaz dzienny KOP nr 32, Warszawa, 21 III 1927 r., 150. 
pobytu na szkoleniu. Wymagało to zmiany i dookreślenia przez dowódcę KOP kryteriów krótkotrwałego szkolenia, do których zaliczono:

- kursy wojskowe dla żołnierzy poszczególnych broni lub służb celem uzupełnienia albo pogłębienia wiedzy fachowej nabytej w wojsku bądź podczas długotrwałej praktyki;

- krótkie kursy, których zadaniem było przeszkolenie osób wojskowych w pewnej dziedzinie pracy służbowej, względnie przysposobienie do niej. Zgodnie z tymi założeniami za normalny (długotrwały) kurs uznawano np. kurs mający na celu nauczenie podkuwnictwa wojskowego podoficera (lub szeregowca), z zawodu ślusarza lub szkolenie dla wojskowych podkuwaczy, którzy nie uczęszczali do zawodowej szkoły podkuwaczy. Uczestnikom takich szkoleń dodatek nie przysługiwał. Natomiast przysługiwał on podoficerom uczestniczącym w kursie dla wyszkolonych podkuwaczy lub po zawodowej szkole wojskowej, a także osobom z długą praktyką. Uczestnikom takich szkoleń przysługiwał dodatek, ale pod warunkiem, że dowódca jednostki kierującej w rozkazie o oddelegowaniu zaznaczył, że słuchacz zachowywał swoje stanowisko etatowe, na które powróci po przeszkoleniu. ${ }^{41}$

Oficerom przydzielonym na przeszkolenie do pułków armii, jeżeli zajmowali stanowiska etatowe, przysługiwał dodatek $\mathrm{w}$ wysokości przewidzianej dla tego stanowiska. Ostatecznie, zgodnie z nowelizacją rozporządzenia wykonawczego z lutego 1927 r., frekwentanci (uczestnicy) krótkotrwałych kursów doszkoleniowych odchodzili na nie z zachowaniem dodatków służbowych przynależnych do zajmowanego stanowiska. ${ }^{42}$

Oficerowie oddani do dyspozycji ministra spraw wojskowych, szefa Sztabu Generalnego, dowódców okręgów korpusów lub dowódcy KOP otrzymywali dodatek służbowy tylko za jeden miesiąc następujący po tym miesiącu, w którym nastąpiło oddanie do dyspozycji. Przez następny okres pozostawania w dyspozycji nie otrzymywali dodatku służbowego aż do czasu objęcia przez nich przewidzianego stanowiska. Przy przeniesieniu służbowym na stanowisko, do którego przypisany był wyższy dodatek od pobieranego ostatnio, przeniesiony przez cały czas oddelegowania otrzymywał dodatek w wyższym wymiarze. Natomiast w przypadku przydziału lub przeniesienia oficerów „W interesie służby" na stanowisko z niższym dodatkiem od pobieranego ostatnio dowódca KOP mógł zezwolić na wypłatę dodatku wyższego w wymiarze pobieranym przed odkomenderowaniem. Oficerowie lub podoficerowie zawodowi pełniący obowiązki w zastępstwie innej osoby, nieobecnej dłużej niż

41 Przykładowo, dowódca KOP rozkazem z 21 III 1927 r. uzupełnił, że dodatek przysługiwał podoficerom odkomenderowanym na kurs funkcyjnych służby weterynaryjnej. Zob. ibid., sygn. 177/13, Rozkaz dzienny KOP nr 32, Warszawa, 21 III 1927 r., 150.

42 Ibid., sygn. 177/12, Rozkaz dzienny KOP nr 77, Warszawa, 20 VIII 1926 r., 253-255; sygn. 177/13, Rozkaz dzienny KOP nr 32, Warszawa, 21 III 1927 r., 150-151. 
dwa miesiące (tj. 60 dni), otrzymywali za cały okres pełnienia służby (od dnia faktycznego rozpoczęcia zastępstwa) dodatek na zasadach jak przeniesieni służbowo. Przy czym bez znaczenia była okoliczność, że zastępcze pełnienie funkcji w przepisowym okresie połączone było z kolejnym zastępstwem dwóch lub więcej osób, o ile zastępstwo to było nieprzerwane..$^{43}$ Natomiast pełniącym obowiązki przysługiwał dodatek w wymiarze należnym dla pełnionej funkcji (stanowiska). ${ }^{44} \mathrm{~W}$ lutym $1935 \mathrm{r}$. na podstawie rozkazu MSWojsk. z 28 marca 1934 r. uszczegółowiono, że oficerowie pełniący zastępczo obowiązki służbowe w okresie dłuższym niż dwa miesiące otrzymywali za cały okres dodatek służbowy według zaszeregowania danego stanowiska, z wyjątkiem przypadków, w których dodatek ten był niższy od ostatnio pobieranego. Bez znaczenia było, czy zastępstwo to pełnione było tylko za jedną, czy też za dwie lub więcej osób, byleby kolejne zastępstwa były nieprzerwane. Zasada ta miała swoje zastosowanie także w przypadkach nieprzerwanego kolejnego zastępstwa w ciągu przepisanego okresu (ponad dwa miesiące) kilku osób na różnych stanowiskach, o ile te były zaszeregowane do wyższej kategorii dodatku niż stanowisko, na którym dany oficer pełnił normalną służbę. Wypłata dodatku służbowego w takich wypadkach następowała po okresie dwóch miesięcy zastępstwa według tej kategorii, do której zaszeregowano stanowisko, na którym oficer pełnił zastępstwo w dniu płatności uposażenia. Przykładowo, oficer będący dowódcą kompanii zastępował od 25 czerwca do 15 lipca urlopowanego dowódcę batalionu, następnie od 16 lipca do 7 sierpnia chorego kwatermistrza i od 8 sierpnia do 7 września nieobecnego dowódcę kompanii szkolnej pułku. Ponieważ zastępstwo to trwało ponad dwa miesiące, to zgodnie $\mathrm{z}$ przepisami należał mu się po 16 sierpnia dodatek za lipiec $\mathrm{w}$ wysokości przewidzianej dla dowódcy batalionu, za sierpień dodatek kwatermistrza, a za wrzesień według zaszeregowania dowódcy kompanii szkolnej pułku (ale pod warunkiem, że w tej kompanii, w tym czasie odbywał się kurs podoficerski). ${ }^{45}$

W sytuacjach, gdy przekazywanie obowiązków danego stanowiska wymagało pewnego czasu i formalnie było ono zajmowane przez dwóch oficerów (zdającego i obejmującego), dodatek służbowy przysługiwał zarówno nowoprzybyłemu, jak i przeniesionemu na to stanowisko, jednak nie dłużej niż na okres jednego miesiąca następującego po tym miesiącu, w którym zmiana została ogłoszona. W takich wypadkach decydował dowódca KOP. ${ }^{46}$

W listopadzie 1926 r. Szefostwo Intendentury KOP, zgodnie z uchwałą Rady Ministrów z 29 października 1926 r. wydaną na podstawie ustawy

\footnotetext{
43 Ibid., sygn. 177/14, Rozkaz nr 8, Warszawa, 28 I 1928 r., 26.

44 Ibid., sygn. 177/12, Rozkaz dzienny KOP nr 77, Warszawa, 20 VIII 1926 r., 253-255; sygn. 177/13, Rozkaz dzienny KOP nr 32, Warszawa, 21 III 1927 r., 150-151.

45 Ibid., sygn. 177/21, Rozkaz nr 10, Warszawa, 15 II 1935 r., 59-60.

46 Ibid., sygn. 177/13, Rozkaz dzienny KOP nr 32, Warszawa, 21 III 1927 r., 150-151.
} 
o uposażeniu funkcjonariuszy państwowych i wojska z 1923 r. oraz na podstawie zarządzenia wiceministra spraw wojskowych, wprowadziło wysokość dodatków służbowych przewidzianych dla podoficerów zawodowych służących w KOP (jak w wojskach lądowych): ${ }^{47}$

Tabela 4. Dodatki służbowe dla podoficerów zawodowych KOP

\begin{tabular}{|c|c|c|}
\hline Kategoria dodatku & Stopień & Liczba punktów \\
\hline I kategoria & chorąży & 90 \\
\hline II kategoria & st. sierżant (równorzędny) & 80 \\
\hline III kategoria & sierżant (równorzędny) & 70 \\
\hline IV kategoria & plutonowy (równorzędny) & 50 \\
\hline V kategoria & kapral (równorzędny) & 30 \\
\hline
\end{tabular}

Źródło: ASGran., Dowództwo KOP, sygn. 177/12, Rozkaz dzienny KOP nr 100, Warszawa, 27 XI 1926 r., 355-356.

Zasady obliczania dodatku obowiązywały od 1 października $1926 \mathrm{r}$. i dlatego miał on zostać wyrównany za październik i listopad. Wydatek na jego pokrycie pochodził $z$ budżetu MSW (dział $5 \$ 1$ ). Nie przysługiwał on chorążym, którzy zajmowali stanowiska etatowo przewidziane dla oficerów i z tego tytułu otrzymywali inny dodatek służbowy. Wymiar tego dodatku nie podlegał zwiększeniu z tytułu otrzymywania dodatku stołecznego. Dodatek nie był uwzględniany przy naliczaniu odpraw $\mathrm{z}$ racji zwolnienia ze służby lub odpraw pośmiertnych. Od kwoty dodatku służbowego naliczany był podatek dochodowy, natomiast nie podlegał on opłatom emerytalnym. Oficerom niezajmującym stanowisk etatowych w KOP (np. będących $\mathrm{w}$ dyspozycji) dodatek służbowy nie przysługiwał, tak samo jak oficerom rezerwy powołanym na ćwiczenia. ${ }^{48}$

Na początku marca 1927 r. uszczegółowiono, że w przypadku podoficerów zawodowych oddelegowanych do szkół i na kursy, którzy pobierali z tego tytułu dodatek za przeniesienie służbowe, przysługiwało także prawo do pobierania dodatku służbowego dla podoficerów zawodowych wg posiadanego stopnia (ale nie funkcji służbowej). Warto dodać, że do 1 października 1926 r., tj. daty wprowadzenia nowej uchwały Rady Ministrów, uczniowie szkół i kursów nie mieli prawa do dodatków służbowych. ${ }^{49}$

47 Uchwała Rady Ministrów zniosła X kategorię, która wynikała z wcześniejszej uchwały z 5 VIII $1926 \mathrm{r}$.

48 ASGran., Dowództwo KOP, sygn. 177/12, Rozkaz dzienny KOP nr 100, Warszawa, 27 XI 1926 r., 355-356; Rozkaz dzienny KOP nr 109, Warszawa, 18 XII 1926 r., 388-389.

49 Ibid., sygn. 177/13, Rozkaz dzienny KOP nr 22, Warszawa, 22 II 1927 r., 107. 
Tabela 5. Dodatkowe stanowiska i ich zaszeregowanie wprowadzone w KOP od 1 stycznia 1927 r.

\begin{tabular}{|c|c|l|c|}
\hline Kategoria & $\begin{array}{c}\text { Liczba } \\
\text { punktów } \\
\text { (uposażenie } \\
\text { zasadnicze) }\end{array}$ & Stanowiska w KOP & $\begin{array}{c}\text { Przeliczenie } \\
\text { wg mnożnej } \\
\mathbf{0 , 4 3} \text { zl }\end{array}$ \\
\hline VI B & 500 & $\begin{array}{l}\text { doradca prawny KOP, zastępca szefa Służby } \\
\text { Intendentury KOP, kierownik Wydziału } \\
\text { Budżetowo-Rachunkowego i Kontroli KOP }\end{array}$ & 215,0 \\
\hline VII B & 300 & $\begin{array}{l}\text { zastępca doradcy prawnego KOP, kierownik } \\
\text { Lotnej Komisji Kontrolnej }\end{array}$ & 129,0 \\
\hline VIII & 250 & $\begin{array}{l}\text { oficerowie wywiadowczy batalionów, dowódcy } \\
\text { kompanii ckm w batalionach, komendant Szkoły } \\
\text { Podoficerów Zawodowych przy KOP, kierownik } \\
\text { kancelarii w Dowództwie KOPa }\end{array}$ & 107,5 \\
\hline
\end{tabular}

a Podniesienie grupy zaszeregowania.

Źródło: ASGran., Dowództwo KOP, 177/13, Rozkaz dzienny KOP nr 32, Warszawa, 21 III 1927 r., $150-151$.

Tabela 6. Dodatkowe stanowiska i ich zaszeregowanie wprowadzone w KOP od 1 lipca 1928 r.

\begin{tabular}{|c|c|l|c|}
\hline Kategoria & $\begin{array}{c}\text { Liczba } \\
\text { punktów }\end{array}$ & \multicolumn{1}{|c|}{ Stanowiska w KOP } & $\begin{array}{c}\text { Przeliczenie } \\
\text { wg mnożnej } \\
\mathbf{0 , 4 3} \text { zl }\end{array}$ \\
\hline VI B & 500 & dowódca Batalionu Szkolnego KOP & 215,0 \\
\hline VII A & 350 & zastępca dowódcy Batalionu Szkolnego & 150,5 \\
\hline VII B & 300 & $\begin{array}{l}\text { komendanci szkół podoficerów niezawodowych, } \\
\text { dowódcy kompanii szkolnych podoficerów } \\
\text { zawodowych i niezawodowych, kwatermistrz } \\
\text { Batalionu Szkolnego, lekarz Batalionu Szkolnego }\end{array}$ & 129,0 \\
\hline VIII & 250 & $\begin{array}{l}\text { komendanci Ośrodków Wyszkolenia Pionierów, } \\
\text { adiutant Batalionu Szkolnego KOP, oficer } \\
\text { oświatowy Batalionu Szkolnego, oficer } \\
\text { materiałowy Batalionu Szkolnego, oficer płatnik } \\
\text { Batalionu Szkolnego, oficerowie młodsi (dowódcy } \\
\text { plutonów) w kompaniach szkolnych }\end{array}$ & 107,5 \\
\hline IX & 150 & oficer żywnościowy Batalionu Szkolnego & 64,5 \\
\hline
\end{tabular}

a Stanowisko zniesione 7 IX 1929 r., w jego miejsce utworzono etat kierownika wyszkolenia przy dowódcy batalionu. Zob. ASGran., Dowództwo KOP, sygn. 177/15, Rozkaz nr 53, Warszawa, 7 IX 1929 r., 274.

Źródło: ASGran., Dowództwo KOP, sygn. 177/14, Rozkaz nr 69, Warszawa, 26 VI 1928 r., 200; Rozkaz nr 79, Warszawa, 3 VIII 1928 r., 230; Rozkaz nr 118, Warszawa, 10 XII 1928 r., 387. 
Tabela 7. Zaszeregowanie stanowisk w KOP utworzonych lub przesuniętych w latach 1929-1934

\begin{tabular}{|c|c|c|c|}
\hline Kategoria & $\begin{array}{c}\text { Liczba } \\
\text { punktów }\end{array}$ & Stanowiska w KOP & $\begin{array}{c}\text { Przeliczenie } \\
\text { wg mnożnej } \\
0,43 \mathrm{zl}\end{array}$ \\
\hline III A & 1200 & dowódca KOP & 516,0 \\
\hline IV B & 800 & $\begin{array}{l}\text { zastępca dowódcy KOP } \mathrm{KO}^{\mathrm{a}} \text {, inspektor formacji } \\
\text { pieszych, inspektor formacji konnych }\end{array}$ & 344,0 \\
\hline $\mathrm{V}$ & 700 & $\begin{array}{l}\text { dowódcy brygad, szef Służby Intendentury KOP, } \\
\text { szef Sztabu KOP }\end{array}$ & 301,0 \\
\hline VI A & 600 & $\begin{array}{l}\text { dowódcy pułków KOP, dowódca Dywizjonu } \\
\text { Żandarmerii KOP, komendant Centralnej Szkoły } \\
\text { Podoficerów (CSP) KOP w Osowcu, inspektorzy } \\
\text { grupy szwadronów, zastępca szefa Intendentury KOP, } \\
\text { zastępca szefa Sztabu KOP, dowódcy batalionów }\end{array}$ & 258,0 \\
\hline VI B & 500 & $\begin{array}{l}\text { kierownik Samodzielnego Referatu Personalnego } \\
\text { Dowództwa KOPb, zastępca komendanta CSP KOP, } \\
\text { szef Oddziału Sztabowego Dowództwa KOP, szef } \\
\text { służby Sztabu KOP, doradca prawny KOP, zastępca } \\
\text { dowódcy Dywizjonu Żandarmerii KOP, komendant } \\
\text { Podoficerów Zawodowych Kawalerii, szef Wydziału } \\
\text { Budżetowo-Rachunkowego KOP, inspektor } \\
\text { Przysposobienia Wojskowego i Wychowania } \\
\text { Fizycznego (PWiWF) KOP, inspektor organów } \\
\text { wywiadowczych KOPc }\end{array}$ & 215,0 \\
\hline VII A & 350 & $\begin{array}{l}\text { zastępca dowódcy Dywizjonu Żandarmerii } \\
\text { KOPd, kwatermistrz CSP KOP, kwatermistrzowie } \\
\text { batalionów, dowódcy kompanii szkolnych CSP } \\
\text { KOP, dowódcy kompanii szkolnych dla podoficerów } \\
\text { niezawodowych przy pułkach lub brygadach, } \\
\text { dowódcy kompanii ckm, naczelny lekarz CSP KOP, } \\
\text { kierownicy referatów sztabu (względnie służby), } \\
\text { kierownicy referatów Dowództwa KOP, zastępcy } \\
\text { szefów oddziałów (względnie służb) Dowództwa } \\
\text { KOP, intendenci brygad, instruktorzy CSP KOP } \\
\text { (mjr.), kierownicy referatów PWiWF KOP }\end{array}$ & 150,5 \\
\hline VII B & 300 & $\begin{array}{l}\text { dowódcy szwadronów, kierownik referatu } \\
\text { oficerskiego Samodzielnego Referatu Personalnego, } \\
\text { kierownik placówki wywiadowczej, oficer } \\
\text { ordynansowy dowódcy KOPe, zastępca szefa } \\
\text { służby (nieprzewidziany nigdzie indziej), zastępca } \\
\text { kierownika Samodzielnego Referatu Wywiadowczego, } \\
\text { lekarze batalionów, lekarz CSP KOP, instruktorzy } \\
\text { CSP KOP (kpt.), lekarze weterynarii i zastępcy } \\
\text { lekarza weterynarii dowództw brygad i szkoły } \\
\text { podoficerów zawodowych kawalerii, kapelani } \\
\text { w dowództwach brygad, oficerowie - instruktorzy } \\
\text { w szkole podoficerów zawodowych kawalerii }\end{array}$ & 129,0 \\
\hline
\end{tabular}




\begin{tabular}{|c|c|c|c|}
\hline VIII & 250 & $\begin{array}{l}\text { adiutant pułku, referent dowództwa pułku, oficer } \\
\text { placówki wywiadowczej, zastępca dowódcy plutonu } \\
\text { żandarmerii przy brygadzie, dowódca plutonu } \\
\text { odwodowego pułku, oficer ordynansowy dowódcy } \\
\text { KOP, kierownik kancelarii Dowództwa KOP, } \\
\text { oficerowie łączności brygad, dowódcy kompanii } \\
\text { w batalionach, dowódcy plutonów łączności } \\
\text { w batalionach, dowódcy kompanii saperów, } \\
\text { dowódcy plutonów w kompaniach szkolnych dla } \\
\text { podoficerów niezawodowych przy brygadach lub } \\
\text { pułkach, komendanci powiatowi PWiWF KOP, } \\
\text { dowódcy plutonów w szwadronach, dowódcy } \\
\text { i zastępcy dowódców plutonów żandarmerii, } \\
\text { dowódcy plutonów odwodowych pułków, } \\
\text { dowódca kompanii sztabowej Dowództwa KOP, } \\
\text { dowódca kompanii administracyjnej CSP KOP, } \\
\text { dowódcy plutonów w kompaniach szkolnych } \\
\text { CSP KOP, dowódcy plutonów ckm, komendant } \\
\text { Szkoły Tresury Psów Meldunkowych, oficerowie } \\
\text { sztabu dowództw brygad, oficerowie intendentury } \\
\text { dowództw brygad, oficerowie ordynansowi } \\
\text { dowódców brygad, adiutanci dowódców pułków, } \\
\text { referenci dowództw pułków, oficerowie łączności } \\
\text { pułków, oficerowie wywiadowczy pułków, płatnik } \\
\text { Dowództwa KOP, oficerowie wywiadowczy } \\
\text { placówek wywiadowczych, adiutant CSP KOP, } \\
\text { oficer administracyjno-materiałowy CSP, płatnik } \\
\text { CSP KOP, oficerowie śledczy żandarmerii, } \\
\text { oficerowie do zleceń, adiutanci batalionów, } \\
\text { oficerowie wywiadowczy batalionów, oficerowie } \\
\text { materiałowi batalionów, płatnicy batalionów, } \\
\text { komendanci ośrodków wyszkolenia pionierów }\end{array}$ & 107,5 \\
\hline IX & 150 & $\begin{array}{l}\text { zastępca kierownika kancelarii Dowództwa KOP, } \\
\text { dowódcy plutonów w kompaniach, dowódcy } \\
\text { plutonów w szwadronach, oficerowie żywnościowi } \\
\text { w batalionach i CSP KOP, zastępcy oficerów } \\
\text { administracyjno-materiałowych w CSP KOP, } \\
\text { dowódcy plutonów kompanii saperów }\end{array}$ & 64,5 \\
\hline X A & - & $\begin{array}{l}\text { dowódca Plutonu Radiotelegraficznego przy } \\
\text { Dowództwie KOPg }\end{array}$ & 105,0 \\
\hline
\end{tabular}

a Wprowadzony w 1931 r. Zob. ASGran., Dowodztwo KOP, sygn. 177/16, Rozkaz nr 43, Warszawa, 11 X 1930 r., 264-265; sygn. 177/17, Rozkaz nr 32, Warszawa, 7 VIII 1931 r., 204. b 1 V 1929 r. utworzono Samodzielny Referat Personalny, który został wyłączony z Oddziału Ogólnego Sztabu Dowództwa KOP i podporządkowany bezpośrednio szefowi Sztabu. Zob. ibid., sygn. 177/15, Rozkaz nr 34, Warszawa, 20 VI 1929 r., 170.

c Stanowisko zostało dodane w maju 1935 r. Zob. ibid., sygn. 177/21, Rozkaz nr 34, Warszawa, 20 V 1935 r., 301.

d Stanowisko istniało do października $1930 \mathrm{r}$.

e Podniesienie zaszeregowania z 250 pkt., następnie w październiku 1930 r. znów obniżone do 250 pkt. 
f Etaty wykreślone w marcu 1931 r. Zob. ibid., sygn. 177/17, Rozkaz nr 9, Warszawa, 9 III 1931 r., 48.

g W 1935 r. w strukturze KOP utworzona została służba łączności. Zob. ibid., sygn. 177/21, Rozkaz nr 64, Warszawa, 25 X 1935 r., 598.

Źródło: ASGran., Dowództwo KOP, sygn. 177/15, Rozkaz nr 34, Warszawa, 20 VI 1929 r., 170; Rozkaz nr 58, Warszawa, 30 IX 1929 r., 290; Rozkaz nr 68, Warszawa, 25 XI 1929 r., 334; Rozkaz nr 69, Warszawa, 4 XII 1929 r., 345; sygn. 177/16, Rozkaz nr 14, Warszawa, 27 III 1930 r., 94; Rozkaz nr 43, Warszawa, 11 X 1930 r., 264-265; sygn. 177/17, Rozkaz nr 9, Warszawa, 9 III 1931 r., 47-48; Rozkaz nr 48, Warszawa, 30 XI 1931 r., 279.

Analiza zachowanych rozkazów dziennych Dowództwa KOP wskazuje, że wysokość dodatku służbowego (jego zwiększenie) mogła zostać przyznana oficerowi imiennie tylko na podstawie rozkazu dowódcy formacji. Przykładowo, w lutym 1930 r. mjr. Eugeniuszowi Oskierce, zastępcy szefa inżynierii KOP, który zaszeregowany był w grupie VII B (tj. 300 pkt.), przyznano dodatek według kategorii VII A (tj. 350 pkt.). ${ }^{50}$

Do marca 1928 r. dodatek służbowy nie przysługiwał podoficerom i szeregowcom służby nadterminowej. Jego wysokość określana była przez ministra spraw wojskowych i ministra skarbu. Był to dodatek do normalnego żołdu wypłacanego żołnierzom według posiadanego stopnia, a jego wysokość wynosiła 50\% należności kaprala zawodowego szczebla "A” z uwzględnieniem $10 \%$ podwyżki (tj. 43,5 pkt, co przy mnożnej 0,43 dawało $18,7 \mathrm{zl}$ ). ${ }^{51}$ Wysokość tego dodatku została jednak zmniejszona w oparciu o rozporządzenie MSWojsk. z 15 maja 1928 r. $^{52}$ Od 1 sierpnia 1928 r. szeregowym nadterminowym przysługiwał dodatek w wysokości 35\% uposażenia kaprala zawodowego $\mathrm{z}$ uwzględnieniem $10 \%$ podwyżki (tj. 34,5 pkt, co dawało $14,84 \mathrm{zl}){ }^{53}$

50 Ibid., sygn. 177/16, Rozkaz nr 7, Warszawa, 18 II 1930 r., 35.

51 Obliczenie na podstawie listy uposażeń Batalionu KOP „Święciany”. Zob. ibid., sygn. 177/636, Lista uposażeń za maj 1928 r., Nowe Święciany, b.d., 246-256.

52 Rozporządzenie ministra spraw wojkkowych z dnia 15 V 1928 r. w sprawie wykonania ustawy z dnia 18 VII 1924 r. o podstawowych obowiązkach i prawach szeregowych Wojska Polskiego, zmienione i uzupełnione rozporządzeniem Prezydenta Rzeczypospolitej z 13 IV 1927 r. Rozporządzenie weszło w życie 20 VII 1928 r., zostało uchylone 19 I 1933 r. (Dz.U. R.P. 1928, nr 71, poz. 643).

53 Rozporządzenie weszło w życie w październiku 1928 r. Zgodnie z nim 35\% dodatek przysługiwał szeregowym nadterminowym mianowanym lub tym, którym przedłużono służbę po 19 X 1928 r., tj. po trzech miesiącach od ogłoszenia rozporządzenia wykonawczego. Pozostałym, którzy zostali nadterminowymi przed 20 X 1928 r., nadal przysługiwał 50\% dodatek dla nadterminowych. Zob. ASGran., Dowództwo KOP, sygn. 177/14, Rozkaz nr 32, Warszawa, 28 III 1928 r., 102; Rozkaz nr 69, Warszawa, 26 VI 1928 r., 200; Rozkaz nr 100, Warszawa, 13 X 1928 r., 320; Rozkaz nr 106, Warszawa, 30 X 1928 r., 333. 
W kategoriach dodatku służbowego należy także traktować dodatek dla podoficerów zawodowych - dowódców strażnic granicznych KOP. Dodatek ten w wysokości 20 zł został wprowadzony na podstawie uchwały Rady Ministrów z 10 września 1930 r. i był wypłacany od 1 października tr. Dodatek dla dowódców strażnic był wypłacany niezależnie od innych przysługujących im dodatków. Nie przysługiwał jednak dowódcom strażnic zawieszonym w czynnościach, odbywającym karę sądową oraz przebywającym na urlopie bez uposażenia. ${ }^{54}$

Prawo do pobierania dodatków służbowych przysługiwało także oficerom rezerwy lub pospolitego ruszenia, którzy czasowo pełnili służbę w KOP jako niezawodowi. Do grupy tej zaliczono oficerów, którzy pozostawali w czynnej służbie w chwili wejścia w życie ustawy uposażeniowej lub powołanych do służby czynnej zarządzeniami (dziennikami personalnymi) ministra spraw wojskowych. Przepisy te nie dotyczyły oficerów powołanych celem odbycia ćwiczeń lub służby wojskowej zarządzeniami Rady Ministrów, powołanych do służby w ramach mobilizacji lub częściowego uzupełnienia stanów wojska na stopie wojennej. ${ }^{55}$

W listopadzie $1932 \mathrm{r}$. na podstawie pisma intendentury, rozkazem dowódcy KOP uszczegółowiono, że w przypadku podoficerów zawodowych zwolnionych od zajęć służbowych na skutek otrzymania kategorii „E” na podstawie orzeczenia komisji rewizyjnej (lekarskiej) należało wypłacać dodatek służbowy najwyżej przez sześć miesięcy, licząc od pierwszego dnia miesiąca następującego po tym miesiącu, w którym nastąpiło zwolnienie. ${ }^{56}$

Przełomowym okresem dla sposobu naliczania uposażeń i dodatków dla oficerów i podoficerów zawodowych KOP był niewątpliwie rok 1934, w którym weszły w życie nowe przepisy rozporządzenia z 28 października 1933 r. o uposażeniu wojska (Dz. U. 1933 r., nr 86, poz. 664). Nowe zasady finansowe znacznie uprościły system wynagrodzeń kadry wojskowej. Zniesiono m.in. dodatki ekonomiczne, szczeble uposażenia i ustalono jednolite stawki, niezależnie od stanu rodzinnego i miejsca pracy żony. Zwiększenie uposażenia uzależnione zostało od awansu, a nie jak było to poprzednio od wysługi lat w danym stopniu wojskowym. Pobory kadry zwolniono od podatku dochodowego i opłat emerytalnych. W miejsce wielu części składowych wprowadzono uposażenie dla poszczególnych stopni z podziałem na kraj i stolicę oraz samotnych i utrzymujących rodzinę. ${ }^{57}$

\footnotetext{
54 Autorowi nie udało się odnaleźć opublikowanej uchwały przywołanej w rozkazie KOP. Jako podstawę podano pismo intendentury: 1.dz.19793/30/Int.Og. Zob. ibid., sygn. 177/16, Rozkaz nr 41, Warszawa, 3 X 1930 r., 255.

55 Ibid., sygn. 177/18, Rozkaz nr 37, Warszawa, 21 X 1932 r., 302.

56 Ibid., Rozkaz nr 42, Warszawa, 10 XI 1932 r., 326.

57 Kusiak zauważa, że na zmianach dodatku rodzinnego stracili, ci, którzy posiadali większe rodziny ( 3 i więcej osób), tj. 32,5\% wszystkich żonatych. W przypadku pułkowników
} 
W oparciu o przepisy powyższego rozporządzenia pod koniec marca 1934 r. Rada Ministrów podjęła uchwałę w sprawie dodatków służbowych dla żołnierzy wojska i marynarki wojennej. Nowością nowego systemu naliczania uposażeń było wprowadzenie nowej tabeli zaszeregowania oficerów ze stałą wysokością przysługującego im dodatku:

Tabela 8. Zaszeregowanie dodatków dla oficerów $\mathrm{KOP}^{58}$

\begin{tabular}{|c|c|c|c|}
\hline \multirow{2}{*}{ Kategoria } & \multicolumn{3}{|c|}{ Wysokość dodatku (z1) } \\
\cline { 2 - 4 } & A & B & C \\
\hline III & 850 & 800 & - \\
\hline IV & 700 & 600 & 425 \\
\hline V & 500 & 450 & 290 \\
\hline VI & 350 & 300 & 260 \\
\hline VII & 280 & 270 & 220 \\
\hline VII & 250 & 225 & 160 \\
\hline IX & 215 & 175 & 155 \\
\hline X & 155 & 155 & 125 \\
\hline XI & 125 & 125 & 105 \\
\hline XII & 105 & 105 & 75 \\
\hline XIII & 75 & 75 & \\
\hline
\end{tabular}

Źródło: Dz. Roz. MSWojsk. 1934, nr 4, poz. 54, 51.

Natomiast dla chorążych oraz podoficerów zawodowych przyjęto stałe stawki dodatku służbowego zależne od posiadanego rzeczywistego stopnia wojskowego.

Tabela 9. Zaszeregowanie dodatków dla podoficerów KOP

\begin{tabular}{|l|c|}
\hline \multicolumn{1}{|c|}{ Stopień } & Wysokość dodatku \\
\hline Chorąży & $35 \mathrm{zl}$ \\
\hline St. sierżant (równorzędny) & $30 \mathrm{zl}$ \\
\hline Sierżant (równorzędny) & $25 \mathrm{zl}$ \\
\hline Plutonowy (równorzędny) & $20 \mathrm{zl}$ \\
\hline Kapral (równorzędny) & $13 \mathrm{zl}$ \\
\hline
\end{tabular}

Źródło: Dz. Roz. MSWojsk. 1934, nr 4, poz. 54, 51.

i podpułkowników zyskali oni 50-60 zł. Pozostali pozornie stracili po 2 zł, ale w praktyce zyskali, gdyż zostali zwolnieni od podatku dochodowego i opłat emerytalnych, które wynosiły ponad 10\% miesięcznych zarobków. Zob. Kusiak, Życie codzienne, 47.

58 Tabela została ograniczona do grupy stanowisk właściwych dla KOP. Poszczególne stanowiska służbowe do odpowiedniej kategorii zaliczał minister spraw wojskowych. Zob. Uchwała Rady Ministrów z 26 III 1934 r. w sprawie dodatków służbowych dla żołnierzy wojska i marynarki wojennej (Dz. Roz. MSWojsk. 1934, nr 4, poz. 54, 50-64). 
Stopnie tytularne nie wpływały na wymiar dodatku. Prawo do otrzymywania dodatku służbowego wygasało w przypadku śmierci, rozwiązania stosunku służbowego, przeniesienia w stan nieczynny, zawieszenia w czynnościach, urlopowania bez uposażenia. W przypadku chorążych pełniących służbę na stanowiskach oficerskich mieli oni prawo do dodatku służbowego w kategorii określonej dla danego stanowiska wg tabeli zaszeregowania. Utrzymane zostały wcześniejsze zasady przyznawania i utraty prawa do pobierania tego dodatku. ${ }^{59}$

W czerwcu 1934 r. dowódca KOP wyjaśnił, że zwolnienie podoficera zawodowego od obowiązków służbowych z powodu złego stanu zdrowia nie pozbawiało go prawa do pobierania dodatku służbowego, gdyż dodatek służbowy dla podoficerów zawodowych był należnością przywiązaną do posiadanego stopnia, nie zaś funkcji/stanowiska. Zwolnienie podoficera zawodowego od obowiązków służbowych pozbawiało go prawa do dodatku jedynie, gdy skutkowało to przeniesieniem w stan nieczynny, zawieszeniem w czynnościach służbowych lub udzieleniem urlopu ponad czas przewidziany w przepisach lub urlopu bez uposażenia, lub w przypadkach, gdy okres choroby lub urlopu dla poratowania zdrowia trwał dłużej niż sześć miesięcy. ${ }^{60}$ Natomiast dodatek przysługiwał podoficerom $\mathrm{w}$ końcowym okresie służby wojskowej w trakcie odbywania praktyki w służbie państwowej (Policja Państwowa, Straż Graniczna, Straż Więzienna, służba skarbowa, leśnictwo), samorządowej lub w przedsiębiorstwach państwowych. ${ }^{61}$ $\mathrm{W}$ związku z koniecznością odbycia praktyki, zgodnie z rozporządzeniem o służbie wojskowej, podoficerom udzielano sześciomiesięcznych urlopów. ${ }^{62}$

W przypadku oficerów dyplomowanych odbywających praktykę po ukończeniu Wyższej Szkoły Wojennej przysługiwał im dodatek służbowy w wysokości otrzymywanej przez okres nauki w tej szkole, chyba że praktykujący zajmował stanowisko etatowe, na którym przysługiwał dodatek służbowy przywiązany do zajmowanego stanowiska. ${ }^{63}$

59 Uchwała Rady Ministrów z 26 III 1934 r. w sprawie dodatków służbowych dla żołnierzy wojska i marynarki wojennej (Dz. Roz. MSWojsk. 1934, nr 4, poz. 54, 50-64); AAN, PRM, sygn. 2/8/0/1.2/I 73, załącznik nr 1 do protokołu PRM z 26 III 1934 r., Warszawa, 26 III 1934 r., $216-218$.

60 ASGran., Dowództwo KOP, sygn. 177/20, Rozkaz nr 31, Warszawa, 15 VI 1934 r., 271.

61 Ibid., Rozkaz nr 38, Warszawa, 27 VII 1934 r., 262.

62 Urlopy celem odbycia praktyki przysługiwały tylko podoficerom zawodowym po przesłużeniu co najmniej 11 lat, do odbycia kursu lub praktyki niezbędnej dla otrzymania stanowisk państwowych, samorządowych lub w przedsiębiorstwach państwowych. Podoficerowie, którzy starali się o posady w instytucjach prywatnych aby odbyć praktykę, musieli zostać przeniesieni w stan nieczynny zgodnie z art. 105 rozporządzenia Prezydenta RP z 7 X 1932 r. o służbie wojskowej podoficerów i szeregowców (Dz.U.R.P. 1932, nr 89, poz. 747). Zob. ASGran., Dowództwo KOP, sygn. 177/22, Rozkaz nr 25, Warszawa, 15 VI 1936 r., 196.

63 ASGran., Dowództwo KOP, sygn. 177/20, Rozkaz nr 49, Warszawa, 5 X 1934 r., 442. 
We wrześniu 1934 r. w związku z wątpliwościami co do terminu powstania prawa do wypłacania dodatku służbowego dla oficerów, na podstawie pisma intendentury uszczegółowiono, że prawo to powstawało z pierwszym dniem najbliższego miesiąca kalendarzowego po dacie objęcia stanowiska. Za dzień objęcia stanowiska należało przyjąć dzień zameldowania się w formacji na skutek wcielenia, przeniesienia lub przydziału. Przykładowo, oficer został przeniesiony 23 marca, zameldował się w nowej formacji 6 kwietnia, ale na skutek urlopu, choroby, przejmowania obowiązków wyznaczone mu stanowisko objął faktycznie 6 maja. W tym przypadku przysługiwało mu prawo do dodatku od 1 maja. W przypadku jednak objęcia stanowiska w pierwszym dniu miesiąca, który był także dniem płatności uposażenia, dodatek przysługiwał już od pierwszego dnia tego miesiąca, w którym objęto stanowisko. Zasada ta obowiązywała także w przypadku, gdy dzień pierwszy miesiąca był wolny od zajęć i $z$ tego powodu objęcie stanowiska nastąpiło w najbliższym dniu zajęć. Przykładowo, z powodu święta objęcie stanowiska nastąpiło 2 listopada, w związku z tym dodatek przysługiwał od 1 listopada. ${ }^{64}$

Tabela 10. Wykaz stanowisk utworzonych w KOP w latach 1936-1938 i kategorie ich zaszeregowania

\begin{tabular}{|c|l|c|}
\hline Kategoria & \multicolumn{1}{|c|}{ Stanowisko w KOP } & Zl \\
\hline III B & Szef Wywiadu KOP & 800 \\
\hline IV A & Komendant CSP KOP „Osowiec” & 700 \\
\hline IV B & Zastępca szefa Wywiadu KOP & 600 \\
\hline V A & $\begin{array}{l}\text { Zastępca komendanta CSP KOP „Osowiec”, inspektor Grupy } \\
\text { Szwadronów Kawalerii KOP }\end{array}$ & 500 \\
\hline V B & Inspektor organów wywiadowczych KOP & 450 \\
\hline VII A & $\begin{array}{l}\text { Zastępca dowódcy batalionu granicznego, dowódca Dywizjonu } \\
\text { Szkolnego Kawalerii KOP „Niewirków” }\end{array}$ & 280 \\
\hline VII B & $\begin{array}{l}\text { Kwatermistrz CSP KOP „Osowiec”, szef intendentury brygady } \\
\text { KOP, kierownik placówki wywiadowczej KOP }\end{array}$ & 270 \\
\hline VIII A & Dowódca kompanii szkolnej CSP KOP „Osowiec” & 2250 \\
\hline VIII B & $\begin{array}{l}\text { Komendant rejonu PW brygady, członek komisji nadzoru } \\
\text { administracyjnego Szefostwa Intendentury KOP, lekarz } \\
\text { weterynarii rejonu, płatnik dowództwa KOP, oficer materiałowy } \\
\text { dowództwa KOP, oficer wyszkolenia pułku KOP }\end{array}$ & \begin{tabular}{l} 
\\
\hline Adiutant pułku/batalionu/ adiutant CSP KOP „Osowiec”, dowódca \\
szwadronu liniowego i dowódca młodych koni Dywizjonu \\
Szkolnego Kawalerii KOP „Niewirków”
\end{tabular} \\
\hline IX A & 215 \\
\hline
\end{tabular}

64 Ibid., Rozkaz nr 45, Warszawa, 6 IX 1934 r., 413; Rozkaz nr 69, Warszawa, 31 XII 1934 r., 582-583. 


\begin{tabular}{|c|l|c|}
\hline IX B & $\begin{array}{l}\text { Lekarz batalionu/pułku, lekarz CSP KOP „Osowiec”, lekarz } \\
\text { weterynarii Dywizjonu Szkolnego Kawalerii KOP „Niewirków”, } \\
\text { oficer wywiadowczy placówki wywiadowczej KOP }\end{array}$ & 175 \\
\hline X A & $\begin{array}{l}\text { Dowódca plutonu kompanii szkolnej CSP KOP „Osowiec”, } \\
\text { dowódca plutonu szwadronu liniowego i dowódca szwadronu } \\
\text { młodych koni Dywizjonu Szkolnego Kawalerii KOP „Niewirków” }\end{array}$ & 155 \\
\hline X B & $\begin{array}{l}\text { Dowódca kompanii gospodarczej CSP KOP „Osowiec”, } \\
\text { komendant powiatu PW - komendant pasa granicznego PW } \\
\text { (batalionu), pomocnik szefa intendentury brygady KOP, oficer } \\
\text { wywiadowczy placówki wywiadowczej KOP, płatnik batalionu, } \\
\text { płatnik CSP KOP „Osowiec, oficer materiałowy batalionu, oficer } \\
\text { materiałowy i oficer żywnościowy CSP KOP „Osowiec”, instruktor } \\
\text { i wykładowca służby saperskiej CSP KOP „Osowiec” }\end{array}$ & 155 \\
\hline XI A & Dowódca plutonu szwadronu kawalerii KOP & 125 \\
\hline
\end{tabular}

Źródło: ASGran., Dowództwo KOP, sygn. 177/22, Rozkaz nr 46, Warszawa, 17 X 1936 r., 351; sygn. 177/24, Rozkaz nr 26, Warszawa, 7 VI 1938 r., 220-221; sygn. 177/49, Rozkaz tajny nr 10, Warszawa, 14 III 1936 r., 50.

\section{Dodatek graniczny}

Specyficznym dodatkiem był dodatek pograniczny (graniczny), który przysługiwał wszystkim żołnierzom zawodowym KOP, za wyjątkiem: pełniących służbę w Warszawie (Dowództwo KOP i Dywizjon Żandarmerii KOP), pozostającym w areszcie śledczym, odbywającym karę sądową, zawieszonym $\mathrm{w}$ czynnościach służbowych, będących $\mathrm{w}$ stanie nieczynnym bez uposażenia, urlopowanym ponad ustawowy czas, delegowanym do Dowództwa KOP lub Dywizjonu Żandarmerii KOP w Warszawie, delegowanym poza obręb KOP, podoficerom korzystającym z urlopu dla odbycia praktyki w państwowej służbie cywilnej, podoficerom i oficerom zawodowym delegowanym na kursy szkół wojskowych w obrębie KOP, ale poza miejscem stałego pobytu służbowego. Żołnierze niepełniący służby z powodu choroby lub urlopu zdrowotnego zatrzymywali dodatek służbowy przez 6 miesięcy, licząc od pierwszego dnia miesiąca następującego po zaprzestaniu pełnienia obowiązków. Dodatek zgodnie z ustawą i rozporządzeniem Prezydenta RP z 9 października 1923 r. o uposażeniu funkcjonariuszów państwowych i wojska (Dz.U.R.P. 1923 r., nr 116, poz. 924) ${ }^{65}$ wypłacany był $\mathrm{z}$ dniem pierwszym najbliższego miesiąca kalendarzowego po powstaniu warunków uzasadniających jego otrzymanie, tzn. wypłacano go „z dołu”. ${ }^{66}$ Dodatek pograniczny, podobnie jak dodatek stołeczny, nie podlegał

65 Ustawa o uposażeniach funkcjonariuszy państwowych i wojska z 9 X 1923 r., weszła w życie 15 XI 1923 r. Podana w Dz. Roz. MSWojsk. 1924, nr 1, poz. 9, 20-28.

66 ASGran., Dowództwo KOP, sygn. 177/12, Rozkaz dzienny KOP nr 94, Warszawa, 28 X 1926 r., 324; sygn. 177/15, Rozkaz nr 46, Warszawa, 9 VIII 1929 r., 232. 
opłatom emerytalnym ${ }^{67}$ oraz nie wchodził do podstawy naliczania odprawy z tytułu zwolnienia do rezerwy lub odprawy pośmiertnej. ${ }^{68}$

Zgodnie z rozkazem gen. dyw. Henryka Minkiewicza (dowódcy KOP) z 24 października 1924 r., oficerom i podoficerom zawodowym pełniącym służbę w brygadach i oddziałach granicznych przysługiwał dodatek pograniczny w wysokości $30 \%$ naliczonych po zsumowaniu uposażenia zasadniczego oraz dodatków regulacyjnego i ekonomicznego dla posiadających rodzinę. Jego wysokość naliczana była na podstawie liczby punktów poszczególnych grup i szczebli uposażenia oficerów i podoficerów oraz liczby punktów obu ww. dodatków. Przykładowo, według wykazu poborów za luty 1925 r. 6 Batalionu KOP w Iwieńcu, mjr Franciszek Studziński (dowódca) i mjr Adam Wilczyński (kwatermistrz) otrzymywali dodatek graniczny w wysokości 274,5 pkt., czyli dla mnożnej 0,44 kwotę 120,78 zł. W przypadku pozostałych oficerów batalionu dodatek graniczny wahał się w zakresie 250,5-138 pkt., tj. 110,22-60,72 zł. Dla podoficerów zawodowych wynosił on od 150 pkt. w przypadku chorążego do 84 pkt. w przypadku kaprala (od 66 do 36,96 zł), a dla kapitulantów (nadterminowych) bez względu na stopień dodatek graniczny wynosił 42 pkt., tj. 18,48 zł. ${ }^{69}$

Żołnierzom służby obowiązkowej pełniącym służbę w KOP na pograniczu przysługiwał dodatek graniczny w wysokości 30\% należnego żołdu (31,5 zł). Dodatek przysługiwał im od dnia rozpoczęcia służby w KOP na granicach (tj. od 1 listopada 1924 r.), jednak w niektórych batalionach błędnie zinterpretowano przepisy i wypłacono dodatek za październik, który jako nienależny miał zostać ściągnięty przez płatników w trzech kolejnych ratach. $^{70}$

Zgodnie z uchwałą Rady Ministrów z 1 kwietnia 1925 r. ${ }^{71}$ dodatek pograniczny oficerów i podoficerów zawodowych KOP pełniących służbę na pograniczu został zwiększony do $40 \%$, a żołnierzom niezawodowym należał się w wysokości $100 \%$ (podwójny żołd). Nie przysługiwał on jedynie pełniącym służbę w Dowództwie KOP, którzy otrzymywali dodatek stołeczny. Należności za dodatek pograniczny miały zostać wypłacone z wyrów-

\footnotetext{
67 Ibid., sygn. 177/11, Rozkaz nr 125, Warszawa, 19 XI 1925 r., 436.

68 Ibid., sygn. 177/13, Rozkaz dzienny KOP nr 15, Warszawa, 10 II 1927 r., 61.

69 Lista poborów z Iwieńca jest jedną z najstarszych list uposażeń KOP zachowanych w zasobie ASGran. Zob. ibid., sygn. 177/665, Listy poborów podoficerów i oficerów Batalionu KOP „Iwieniec”, Iwieniec, luty 1925 r., 1-9.
}

70 Dodatki graniczne wypłacane były $\mathrm{z} \$ 1$ (uposażenie), poz. Ib-IIb, w utworzonym w 1924 r. dziale VII budżetu MSW. Zob. ibid., sygn. 177/10, Rozkaz dzienny nr 2, Warszawa, 24 X 1924 r., 6, 8; Rozkaz dzienny KOP nr 6, Warszawa, 14 XI 1924 r., 28; Rozkaz dzienny KOP nr 16, Warszawa, 13 XII 1924 r., 55; sygn. 177/12, Rozkaz dzienny KOP nr 94, Warszawa, 28 X 1926 r., 324.

71 Autorowi nie udało się odnaleźć opublikowanej uchwały z 1 IV 1925 r. 
naniem od 1 stycznia $1925 \mathrm{r}^{72} \mathrm{~W}$ przypadku wzmiankowanego powyżej mjr. Studzińskiego z Iwieńca jego dodatek graniczny zwiększył się o 87,5 pkt, czyli o 38,5 zł. Pozostali oficerowie tego batalionu otrzymywali dodatki graniczne w wysokości 370-180 pkt., tj. 162,8-79,2 zł, podoficerowie zawodowi od 193 do 108 pkt., czyli 84,92-47,52 zł, a kapitulanci (nadterminowi) 54 pkt., tj. 23,76 zł. ${ }^{73}$ Oficerom i podoficerom zawodowym przydzielonym służbowo lub oddelegowanym do innej brygady nadal przysługiwał $40 \%$ dodatek graniczny oraz dodatek za przeniesienie/oddelegowanie. Natomiast przeniesionym z brygady do Dowództwa KOP w Warszawie ${ }^{74}$ przysługiwało uposażenie bez dodatku granicznego, ale $\mathrm{z}$ dodatkiem $\mathrm{z}$ tytułu przeniesienia/odkomenderowania. Przeniesionym służbowo lub oddelegowanym z Warszawy do brygad KOP przysługiwało uposażenie z dodatkiem stołecznym oraz normalny dodatek za przeniesienie/oddelegowanie. ${ }^{75}$

$\mathrm{Z}$ dniem 1 stycznia 1926 r. zgodnie z pismem Ministerstwa Skarbu z 23 grudnia 1925 r. żołnierzom zawodowym i niezawodowym KOP pełniącym służbę na granicy przysługiwał $25 \%$ dodatek pograniczny. ${ }^{76}$ Naliczany był na podstawie poborów zasadniczych i dodatku do uposażenia (10\%) i stanowił $25 \%$ ich sumy. Jego otrzymywanie przez żołnierzy wykluczało pobieranie innych dodatków służbowych, tj. dodatku dla ciężko pracujących. Z tego też względu w budżecie formacji na lata 1925-1926 nie zabezpieczano środków finansowych na taki dodatek. ${ }^{77}$ Od 1 kwietnia $1928 \mathrm{r}$. dodatek pograniczny przysługiwał także podoficerom nadterminowym za czas ich faktycznego pełnienia służby w jednostkach KOP ( $\mathrm{z}$ wyłączeniem Dowództwa KOP).$^{78}$

Oficerowie i podoficerowie zawodowi KOP, pobierający dodatek pograniczny w czasie niepełnienia służby z powodu choroby lub urlopu dla poratowania zdrowia, otrzymywali ten dodatek przez okres sześciu miesięcy, licząc od pierwszego dnia miesiąca następującego po dacie wystąpienia

\footnotetext{
72 Jako podstawę wydania rozkazu KOP podano pismo: ldz. KOP 2236/Int. Zob. ibid., sygn. 177/11, Rozkaz nr 42, Warszawa, 4 V 1925 r., 135.

73 Według danych statystycznych w 1925 r. odnotowano przeciętne ceny: chleb żytni (kg) 0,49 zł, mleko (kg) - 0,4 zł, ziemniaki (kg) - 0,11 zł, masło (kg) - 5,64 zł, mięso wieprzowe (kg) - 1,96 zł, kiełbasa (kg) - 3,19 zł, papierosy (100 szt.) - 3 zł. Koszt zakupu konia wahał się od 171 do 269 zł, dojnej krowy 171-218 zł. Zob. ibid., sygn. 177/665, Lista płacy za listopad 1925 r. oficerów, podoficerów zawodowych, Iwieniec, 1925 r., 16-31; Rocznik statystyki, 236-237.

74 Także na teren woj. śląskiego i Rembertowa.

75 ASGran., Dowództwo KOP, sygn. 177/11, Rozkaz nr 110, Warszawa, 15 X 1925 r., 404; sygn. 177/17, Rozkaz nr 33, Warszawa, 20 VIII 1931 r., 209.

76 Ibid., sygn. 177/12, Rozkaz dzienny KOP nr 6, Warszawa, 18 I 1926 r., 19.

77 Ibid., Rozkaz dzienny KOP nr 49, Warszawa, 22 V 1926 r., 174.

78 Ibid., sygn. 177/14, Rozkaz nr 32, Warszawa, 28 III 1928 r., 100-102.
} 
choroby lub urlopu ${ }^{79}$ (tj. na zasadach jak przy dodatku służbowym). Podobnie w przypadku długotrwałej delegacji służbowej dodatek pograniczny nie przysługiwał. Przykładowo, jeżeli osoba delegowana wyjechała ze swojego batalionu w dniu 3 lipca do Warszawy, gdzie zakończyła swoje czynności 27 października, to przysługiwał jej dodatek pograniczny za lipiec, którego nie należało potrącać. Nie należał się jej jednak dodatek graniczny za sierpień, wrzesień i październik, a po powrocie do jednostki prawo do tego dodatku powstawało od 1 listopada. W grudniu 1929 r. dowódca KOP polecił potrącenie dodatku pogranicznego oficerom, którzy zostali powołani na kurs próbny przy Wyższej Szkole Wojennej. Wystawiono im jedynie delegacje służbowe. ${ }^{80}$

W 1932 r. w związku z uchwałą Rady Ministrów z 7 stycznia w sprawie dodatku pogranicznego dla wojskowych zawodowych oraz szeregowych nadterminowych Korpusu Ochrony Pogranicza ${ }^{81} 19$ stycznia ukazał się kolejny rozkaz dowódcy KOP, który zasadniczo potwierdzał dotychczasowe zasady jego wypłacania. Tak jak w poprzednich latach $40 \%$ dodatek przysługiwał oficerom i podoficerom zawodowym KOP, 25\% nadterminowym żołnierzom KOP oraz 100\% szeregowym służby czynnej w jednostkach KOP. Zgodnie z ustawą z 9 października 1923 r. o uposażeniu funkcjonariuszów państwowych i wojska, dodatek pograniczny naliczany był od uposażenia. Do grupy osób wojskowych wyłączonych z pobierania dodatku dodani zostali pozostający bez przydziału służbowego ponad miesiąc oraz delegowani poza obręb KOP. ${ }^{82} \mathrm{~W}$ listopadzie $1932 \mathrm{r}$. uszczegółowiono, że w przypadku podoficerów zawodowych zwolnionych od zajęć służbowych na skutek otrzymania kategorii „E” na podstawie orzeczenia komisji rewizyjnej, należało wypłacać dodatek pograniczny najwyżej przez miesiąc, licząc od pierwszego dnia miesiąca następującego po tym miesiącu, w którym nastąpiło zwolnienie. ${ }^{83}$

Po wprowadzeniu w 1933 r. nowych przepisów o uposażeniu wojska nastąpiły m.in. zmiany zasad wypłacania dodatku pogranicznego. Znowelizowano także przepisy dotyczące innych dodatków o charakterze granicznym. Na podstawie art. 8 ust. 1, art. 28 ust. 1 i art. 37 rozporządzenia o uposażeniu wojska (Dz.U.R.P. 1933, nr 86, poz. 664) 28 stycznia 1934 r. uchwałą Rady Ministrów wprowadzony został dodatek do uposażenia dla

\footnotetext{
79 Ibid., sygn. 177/12, Rozkaz dzienny KOP nr 113, Warszawa, 24 XII 1926 r., 415.

80 Ibid., sygn. 177/15, Rozkaz nr 72, Warszawa, 20 XII 1929 r., 365; sygn. 177/16, Rozkaz nr 36, Warszawa, 3 IX 1930 r., 229.

81 Autorowi nie udało się odnaleźć opublikowanej uchwały Rady Ministrów z 7 I 1932 r.

82 Podstawą wydania rozkazu było pismo nr 560/32/Int.Og z 15 I 1932 r. Zob. ASGran., Dowodztwo KOP, sygn. 177/18, Rozkaz nr 2, Warszawa, 19 I 1932 r., 7.
}

83 Ibid., Rozkaz nr 42, Warszawa, 10 XI 1932 r., 326. 
żołnierzy pełniących służbę w KOP. Uchwała weszła w życie z dniem 1 lutego $1934 \mathrm{r}^{84}$ Ten dodatek graniczny, ze względu na szczególne warunki służby, przysługiwał oficerom zawodowym i rezerwy powołanym do służby czynnej (przed przemianowaniem na zawodowych), podoficerom zawodowym i nadterminowym oraz podoficerom i szeregowcom pełniącym obowiązkową służbę czynną w KOP. Dodatek był stałą stawką zależną od stopnia i stanu rodzinnego. W przypadku oficerów i podoficerów zawodowych oraz nadterminowych wypłacany był wraz z uposażeniem za dany miesiąc, natomiast podoficerom i szeregowcom obowiązkowej służby czynnej dekadowo wraz z żołdem. ${ }^{85}$

Tabela 11. Wysokość dodatków granicznych dla oficerów i podoficerów zawodowych KOP

\begin{tabular}{|l|c|c|}
\hline \multicolumn{1}{|c|}{ Stopień } & Samotni (zł) & Utrzymujący rodzinę (zł) \\
\hline Pułkownik & 144 & 154 \\
Podpułkownik & 122 & 131 \\
Major & 100 & 108 \\
Kapitan (równorzędny) & 77 & 86 \\
Porucznik & 62 & 72 \\
Podporucznik & 47 & 57 \\
Chorąży & 53 & 66 \\
St. sierżant (równorzędny) & 44 & 57 \\
Sierżant (równorzędny) & 38 & 51 \\
Plutonowy (równorzędny) & 33 & 41 \\
Kapral (równorzędny) & 30 & 37 \\
Nadterminowi & 10 & - \\
\hline
\end{tabular}

Źródło: ASGran., Dowództwo KOP, sygn. 177/496, „Kalendarz informacyjny dla podoficerów zawodowych na rok 1939/40", Warszawa, 1939 r., 177-178; Uposażenie wojska, 386.

Wysokość dodatku dla podoficerów i szeregowców pełniących obowiązkową służbę czynną wynosiła na dekadę: plutonowy (równorzędny) 2,15 zł, kapral (równorzędny) - 1,7 zł, st. strzelec (równorzędny) - 1,07zł, strzelec (równorzędny) - 0,85 zł. ${ }^{86}$

Podobnie jak w latach wcześniejszych, wyłączeni od pobierania dodatku granicznego byli pełniący służbę (w tym oddelegowani) w Dowództwie KOP i Dywizjonie Żandarmerii KOP w Warszawie, pozostający w areszcie

${ }^{84}$ Autorowi nie udało się odnaleźć opublikowanej uchwały z 28 I 1934 r. Zob. Uposażenie wojska oraz funkcjonariuszów państwowych i kontraktowych administracji wojskowej. Zbiór aktualnych przepisów uzupetnione wyczerpującymi objaśnieniami (Warszawa: Koło Oficerów Intendentów, 1939), 381-382.

85 Ibid., 382.

86 Ibid., 386. 
śledczym, zawieszeni w czynnościach służbowych, odbywający karę sądową, pozostający w stanie nieczynnym bez uposażenia, na urlopie ponad czas ustawowy, delegowani poza obręb KOP, podoficerowie zawodowi na urlopie dla odbycia praktyki w państwowej służbie cywilnej, oddelegowani na kursy do szkół wojskowych KOP poza miejscem pełnienia służby. W przypadku żołnierzy niepełniących służby z powodu choroby, urlopu dla poratowania zdrowia lub $\mathrm{w}$ trakcie postępowania rewizyjno-lekarskiego zatrzymywali dodatek przez sześć miesięcy, licząc od pierwszego dnia miesiąca po zaprzestaniu pełnienia czynności służbowych. Żołnierze oddani do dyspozycji, ewentualnie pozbawieni przydziału służbowego, otrzymywali dodatek tylko przez jeden miesiąc. ${ }^{87}$

Przy okazji dodatków granicznych należy wspomnieć, że pomimo nowelizacji uchwały w sprawie dodatków dla podoficerów zawodowych KOP pełniących funkcję dowódców strażnic (28 stycznia 1934 r.) nadal otrzymywali oni dodatek funkcyjny w niezmienionej wysokości $20 \mathrm{zł}$ miesięcznie. ${ }^{88}$ Według dyslokacji KOP z połowy 1939 r. była to grupa 310-315 podoficerów w skali całej formacji. ${ }^{89}$ Ponadto od 1938 r., w związku z utworzeniem w strukturze batalionów i kompanii granicznych KOP etatowych stanowisk podoficerów granicznych, ${ }^{90}$ wprowadzono przeznaczony dla nich specjalny dodatek funkcyjny. Ustanowiono go uchwałą Rady Ministrów z 19 marca 1938 r. (weszła w życie od 1 kwietnia). ${ }^{91}$ Dodatek ten w wysokości 20 zł przysługiwał podoficerom zawodowym obsadzonym na etatowych stanowiskach podoficerów granicznych. Wypłacany był co miesiąc, a prawo do jego otrzymania powstawało z pierwszym dniem miesiąca kalendarzowego, w którym nastąpiło objęcie funkcji, natomiast ustawało wraz z pierwszym dniem miesiąca kalendarzowego, w którym nastąpiło jego przeniesienie, zawieszenie w czynnościach lub rozpoczęcie kary sądowej. Podobnie jak

\footnotetext{
87 ASGran., Dowództwo KOP, sygn. 177/496, Kalendarz informacyjny dla podoficerów zawodowych na rok 1939/40, Warszawa, 1939 r., 191-192; Uposażenie wojska, 385-387.

88 Uposażenie wojska, 390-391.

89 ASGran., Dowództwo KOP, sygn. 177/148, Komunikat dyslokacyjny KOP 1934, Warszawa, 7 VI 1934 r., 1-36.
}

90 Stanowiska podoficerów granicznych utworzone zostały w każdej kompanii granicznej oraz w dowództwie każdego batalionu granicznego, w tym także w Batalionie KOP „Suwałki”, który miał charakter mieszany, tj. graniczno-odwodowy. Szerzej o podoficerach granicznych: Ochał, „Podoficerowie graniczni Korpusu Ochrony Pogranicza w systemie zabezpieczenia kontrwywiadowczego pogranicza II Rzeczypospolitej," w Kontrwywiad II RP (1914) 1918-1945 (1948), t. 3, red. Zbigniew Nawrocki (Warszawa-Emów: Agencja Bezpieczeństwa Wewnętrznego. Centralny Ośrodek Szkolenia im. gen. dyw. Stefana Roweckiego „Grota”, 2015), 209-229.

91 Autorowi nie udało się odnaleźć opublikowanej uchwały z 19 III 1938 r. Zob. Uposażenie wojska, 389-390. 
w przypadku dodatku granicznego, pozostający na leczeniu lub na urlopie celem poratowania zdrowia zatrzymywali prawo do dodatku przez jeden miesiąc. W przypadku zastępstwa, zastępującemu przysługiwał dodatek w przypadku pełnienia tej funkcji przez okres powyżej dwóch miesięcy. ${ }^{92}$ W połowie 1939 r. w całej formacji pełniło służbę blisko 110 podoficerów granicznych. Dodatki dla dowódców strażnic i podoficerów granicznych wypłacane były niezależnie od dodatków granicznych.

Przykładowo, w kwietniu 1939 r. sierż. Stanisław Chmielewski, dowódca strażnicy KOP „Soczewki” (Batalion KOP „Budsław”), jako utrzymujący rodzinę otrzymał uposażenie w wysokości 337 zł, w tym: 241 zł uposażenia zasadniczego, $25 \mathrm{zł}$ dodatku służbowego, $51 \mathrm{zł}$ granicznego i $20 \mathrm{zł}$ jako dowódca strażnicy. Z uposażenia potrącono mu $28,89 \mathrm{zl}$, z tego: 24,19 zł podatku, 1,25 zł na fundusz społeczny KOP, 1,5 zł za prenumeratę „Wiarusa”, 1,55 zł na pomoc zimową i 1 zł na Podoficerskie Domy Wypoczynkowe. Po potrąceniach otrzymał „na rękę" 308,11 zł. Pełniący służbę w tej samej kompanii sierż. Wacław Danielkiewicz, podoficer graniczny, otrzymał podobne pobory, z tym że wypłacono mu dodatek dla podoficerów granicznych ( $20 \mathrm{zł})$, ale do potrąceń dodano mu $0,15 \mathrm{zł}$ za pomieszczenie mieszkalne, dlatego pokwitował 307,96 zł. W tym samym miesiącu rtm. Marian Szalewicz, dowódca Szwadronu KOP „Budsław”, jako utrzymujący rodzinę otrzymał uposażenie w wysokości 651 zł, w tym: 400 zł zasadniczego, 125 zł dodatku służbowego, 86 zł granicznego i $40 \mathrm{zł}$ ekwiwalentu za usługi ordynansa. Po potraceniach (łącznie 67,21 zł) otrzymał 536,88 zł. ${ }^{93}$

\section{Podsumowanie}

Ze względu na obszerność zagadnienia, z konieczności w artykule omówiono tylko najważniejsze dodatki do uposażenia KOP, czyli wyrównawczy, służbowy i graniczny. Pozostałe wynikające $\mathrm{z}$ ich sytuacji rodzinnej, ze szczególnego charakteru służby lub posiadanych umiejętności, zostaną omówione w odrębnym opracowaniu. W artykule pominięto kwestie zwrotu kosztów podróży i przeniesień oraz związanych $\mathrm{z}$ nimi przewozów mienia domowego, które nie miały charakteru dodatków. Niektóre $\mathrm{z}$ omówiony dodatków (np. wyrównawczy) były wynikiem zmian zasad naliczania uposażenia wojska i funkcjonariuszy państwowych wprowadzonych w latach 1923 i 1933. Oczywiście prawodawca (tj. Rada Ministrów), wprowadzając w życie kolejne uchwały w kwestiach płac i dodatków, starał się przewidzieć różnorakie sytuacje z udziałem wojska, choć w 1923 r. nie mógł przypuszczać, że sytuacja na

\footnotetext{
92 ASGran., Dowództwo KOP, sygn. 177/23, Rozkaz nr 14, Warszawa, 4 IV 1938 r., 90-91.

93 Ibid., sygn. 177/654, Wykazy uposażeń odwodu Baonu KOP „Budsław” i 1 kompanii „Olkowicze”, Budsław, kwiecień 1939 r., 415-1417.
} 
Kresach Wschodnich II Rzeczypospolitej wymusi utworzenie KOP. Po utworzeniu formacji i przydzieleniu do niej kadry zawodowej, której przyszło służyć w kresowych warunkach, konieczne stało się uchwalenie dodatku granicznego. Dodatek ten, oprócz gratyfikacji za trudy służby na pograniczu, był także swoistą „szczepionką antykorupcyjną" mającą uodpornić żołnierzy KOP przed ewentualnym łapownictwem i korupcją. Doświadczenia wcześniejszych formacji ochrony granicy wykazały, że źle opłacany i słabo wyposażony żołnierz lub funkcjonariusz był nieodporny na przekupstwa ze strony przemytników. Należy przy tym pamiętać, że słabo wynagrodzony mógł stać się podatny na komunistyczną agitację ze strony komunistycznych agentów i agitatorów Związku Radzieckiego. Oczywiście nie wszyscy żołnierze byli odpowiednio „odporni” i także w KOP zdarzały się przypadki łapownictwa, ale jest to rzeczą naturalną w każdej formacji porządkowej.

Kwestią, którą warto poruszyć na koniec niniejszych rozważań, jest pytanie zadane we wstępie artykułu, tj. czy żołnierze zawodowi KOP byli dużo lepiej uposażeni niż pozostali żołnierze Wojska Polska? Według danych podanych w Matym roczniku statystycznym 1935 w 1934 r. wykwalifikowany robotnik zarabiał w Polsce 95,6 zł miesięcznie. ${ }^{94}$ Lepiej powodziło się urzędnikom umysłowym, którzy otrzymywali średnio 280 zł miesięcznie, a komisarz Policji Państwowej przynosił do domu pobory w wysokości 335 zł. W przypadku oficerów Wojska Polskiego oficer młodszy w stopniu kapitana utrzymujący rodzinę otrzymywał średnio $400 \mathrm{zł}$ (samotny miał $345 \mathrm{zł)} \mathrm{oraz} \mathrm{dodatek} \mathrm{służ-}$ bowy $105 \mathrm{zl}$, ale już kapral zawodowy z rodziną $167 \mathrm{zł}$ miesięcznie (samotny 137 zł). ${ }^{95}$ Zarobki te można przyrównać do uposażeń subiektywnie wybranych oficerów i podoficerów Batalionu Fortecznego KOP „Sarny” z maja 1939 r. $\mathrm{Z}$ dniem 1 kwietnia tego roku mjr Zygmunt Reliszko, dowódca 4 kompanii, został zaszeregowany w grupie VIII A z dodatkiem służbowym 155 zł, a kpt. Władysław Raginis, dowódca plutonu w tej kompanii (we wrześniu 1939 r. bohaterski obrońca Wizny), w grupie X A z dodatkiem 105 zł. ${ }^{96}$ Major Reliszko jako żonaty miał uposażenie zasadnicze w wysokości $490 \mathrm{zl}$, dodatek lokalny $108 \mathrm{zł}$ i ekwiwalent za ordynansa 40 zł. Po potrąceniach wypłacono mu 519,77 zł. Natomiast uposażenie kpt. Raginisa jako samotnego wyniosło „na rękę” 344,12 zł. $\mathrm{W}$ tym samym miesiącu st. sierż. Franciszek Frąckowiak otrzymał po potrąceniach 274,78 zł, a kpr. zaw. Bernard Adamczak (obaj z 4 kompanii) 132,54 zł. ${ }^{97}$ To proste zestawienie nie wykazuje, aby uposażenia oficerów i podoficerów

94 Mały rocznik statystyczny 1935 (Warszawa: Główny Urząd Statystyczny, 1935), 166.

95 Mały rocznik statystyczny 1939 (Warszawa: Główny Urząd Statystyczny, 1939), 270; JK/ MM, „Panie Marszałku, jak żyć? Ceny i zarobki w II RP,” Newsweek, maj 29, 2013.

96 ASGran., Brygada KOP „Polesie”, sygn. 183/108, Rozkaz nr 26, Łachwa, 31 III 1938 r., 84.

97 Ibid., Dowództwo KOP, sygn. 177/690, Wykaz uposażenia miesięcznego oficerów i podoficerów 4 kompanii Batalionu KOP „Sarny” za miesiąc maj 1939 r., Sarny, maj 1939 r., 167-170. 
zawodowych służących w KOP były większe niż pozostałych wojskowych i to pomimo wypłacanego im dodatku granicznego. Na tej podstawie można wnioskować, że przeświadczenie o ich wyższych zarobkach było błędne, a ich lepsza sytuacja finansowa wynikała $\mathrm{z}$ innych przyczyn. Służba $\mathrm{w}$ warunkach małych, kresowych garnizonów znacząco ograniczała wydatki na codzienne życie. Mniej było tam rautów i przyjęć generujących koszty, a życie towarzyskie było dużo mniej wystawne niż w dużych miastach. Łatwiej i taniej można było kupić na terenach pogranicza produkty rolne, choć może nie wszędzie w równym stopniu, ale pomimo to lżej i spokojniej było tam żyć. Niewątpliwie dużą niedogodnością dla dzieci kadry zawodowej był trudniejszy dostęp do edukacji oraz do specjalistycznej opieki medycznej, ale zagadnienie to wymaga szerszych badań, które wykraczają poza obręb tego artykułu.

\section{Bibliografia}

Archiwalia

Archiwum Akt Nowych

Prezydium Rady Ministrów (1917-1939)

Archiwum Straży Granicznej w Szczecinie

Brygada KOP „Polesie”

Dowództwo KOP

Straż Graniczna 1928-1939

\section{Dokumenty drukowane}

Jabłonowski, Marek, Włodzimierz Janowski, Bogusław Polak i Jerzy Prochwicz, oprac. O Niepodległa i granice. Korpus Ochrony Pogranicza 1924-1939. Wybór dokumentów. Warszawa-Pułtusk: Wyższa Szkoła Humanistyczna, Wydział Dziennikarstwa i Nauk Politycznych Uniwersytetu Warszawskiego, 2001.

Mały rocznik statystyczny 1935. Warszawa: Główny Urząd Statystyczny, 1935.

Mały rocznik statystyczny 1939. Warszawa: Główny Urząd Statystyczny, 1939.

Rocznik statystyki Rzeczypospolitej Polskiej. Warszawa: Główny Urząd Statystyczny, 1927. Uposażenie wojska oraz funkcjonariuszów panstwowych i kontraktowych administracji wojskowej. Zbiór aktualnych przepisów uzupetnione wyczerpującymi objaśnieniami. Warszawa: Koło Oficerów Intendentów, 1939.

\section{Opracowania}

Dominiczak, Henryk. Granica wschodnia Rzeczypospolitej Polskiej w latach 19191939. Warszawa: Wyd. Naukowe PWN, 1992.

Jabłonowski, Marek. Formacja specjalna. Korpus Ochrony Pogranicza 1924-1939. Warszawa: Ofic. Wyd. ASPRA-JR, 2002/2003.

Kusiak, Franciszek. Życie codzienne oficerów drugiej Rzeczypospolitej. Warszawa: Państwowy Instytut Wydawniczy, 1992.

Ochał, Artur. „Podoficerowie graniczni Korpusu Ochrony Pogranicza w systemie zabezpieczenia kontrwywiadowczego pogranicza II Rzeczypospolitej." 
W Kontrwywiad II RP (1914) 1918-1945 (1948). T. 3. Red. Zbigniew Nawrocki, 209-229. Warszawa - Emów: Agencja Bezpieczeństwa Wewnętrznego. Centralny Ośrodek Szkolenia im. gen. dyw. Stefana Roweckiego „Grota”, 2015.

Ochał, Artur. Tarcza II Rzeczypospolitej. Korpus Ochrony Pogranicza 1924-1939. Warszawa: Wyd. Instytutu Pamięci Narodowej, 2018.

Prochwicz, Jerzy, Andrzej Konstankiewicz i Jan Rutkiewicz, Korpus Ochrony Pogranicza 1924-1939. Warszawa: Barwa i Broń, 2003.

Stawecki, Piotr. Z dziejów wojskowości Drugiej Rzeczypospolitej. Pułtusk: Wyższa Szkoła Humanistyczna, 2001.

\section{Prace niewydane}

Chojnacki, Jan. „Płocczanin Zdzisław Chojnacki 1900-1966.” Warszawa 1997, mps w zbiorach autora.

Prasa

JK/MM, „Panie Marszałku, jak żyć? Ceny i zarobki w II RP” Newsweek, maj 29, 2013.

\section{STRESZCZENIE}

\section{Artur Ochał, Dodatek graniczny i dodatki służbowe do uposażenia żołnierzy Korpusu Ochrony Pogranicza (1924-1939)}

W przekonaniu społeczeństwa II Rzeczypospolitej żołnierze służący w Korpusie Ochrony Pogranicza byli dużo lepiej opłacani od pozostałych służących w jednostkach armii. Szczególnie, że po 1926 r. status materialny kadry Wojska Polskiego stale wzrastał. Z czasem uposażenie wojskowych stało się przedmiotem zazdrości włościan i urzędników. Wysokie pensje oficerów i ich uprzywilejowana pozycja zaczęły drażnić społeczeństwo, które czuło się pomijane i lekceważone przez państwo.

KOP będący specjalną formacją wojskową, finansowaną przez Ministerstwo Spraw Wewnętrznych, w zakresie płac podlegał przepisom o uposażeniach funkcjonariuszy państwowych i wojska. W początkowym okresie była to ustawa z 1923 r., która określała, że wysokość uposażenia zasadniczego żołnierzy naliczana była na podstawie wprowadzonej ustawą tabeli szczebli i grup uposażenia. W 1934 r. weszły w życie przepisy nowego rozporządzenia, które znacznie uprościły system wynagrodzeń kadry wojskowej.

Rozporządzenia o uposażeniach wojska miały charakter ogólny, bez uwzględniania specyfiki służby KOP. Szczegółowe wytyczne finansowe dotyczące dodatków służbowych wydano w formie rozkazów dowódcy KOP, które nie były dotąd analizowane przez historyków. Celem artykułu jest przedstawienie zasad przyznawania w ramach KOP dodatków służbowych do uposażenia, ich wysokości i okoliczności przydzielania. Omówieniu poddano m.in. kwestie przydziału dodatków wyrównawczych, wysokości i zasad przyznawania dodatków służbowych, granicznych oraz funkcyjnych. Dodatki oprócz gratyfikacji za trudy służby na pograniczu miały uodparniać żołnierzy KOP na łapownictwo, gdyż źle opłacany żołnierz był podatny 
na przekupstwa ze strony przemytników lub łatwo mógł poddać się agitacji ze strony Związku Radzieckiego.

Słowa kluczowe: Polska 1918-1939, Korpus Ochrony Pogranicza, uposażenie żołnierzy zawodowych

\section{SUMMARY}

\section{Artur Ochat, The Salaries and the Allowances (Border and Service) of Soldiers of the Border Protection Corps (1924-1939)}

The general opinion held by the society of the Second Polish Republic, was that soldiers who served in the Border Protection Corps (KOP) were much better paid than those in other army units. This was especially true after 1926, a time when the material status of the personnel serving in the Polish Army was constantly increasing. Over time, military pay became the envy of both peasants and officials, and together with the privileged positions held by army officers these salaries began to irritate a society that felt ignored and disregarded by the state.

The KOP, which was a special military formation financed by the Ministry of the Interior, was, in terms of payroll, subject to the provisions regarding the salaries of state officials and the army. Initially, an act of 1923 specified that the basic salary of soldiers was to be calculated based on a table of ranks and salary groups that was included in the act. In 1934 a new order came into force, which significantly simplified the remuneration system for military personnel.

The regulations concerning military salaries were of a general nature, without considering the specific nature of the KOP. Detailed financial guidelines regarding service allowances were issued in the form of orders from the KOP commander, which have not been analyzed by historians. The aim of the article is to understand the principles behind the granting of service allowances under the KOP, their amount and the circumstances surrounding their allocation. The discussion covers, inter alia, issues regarding the allocation of compensatory allowances, and the amount and rules for granting service, border, and functional allowances. The bonuses, apart from providing compensation for the hardships endured during service on the border, were an attempt to immunize the KOP soldiers from financial corruption, because a poorly paid soldier was susceptible to bribery by smugglers or could easily be 'bought' by Soviet agents.

Keywords: Poland 1918-1939, military history, Border Protection Corps, military salaries

\section{АННОТАЦИЯ}

\section{Артур Охал, Пограничные и служебные надбавки к окладу военнослужащих Корпуса охраны пограничья (1924-1939)}

Согласно убеждениям жителей Второй Польской республики, солдаты, служившие в Корпусе охраны пограничья, получали гораздо больший оклад, 
чем остальные служащие в других военных подразделениях. Тем более, что после 1926 г. материальное положение личного состава Войска Польского постоянно повышалось. Со временем зарплаты военных стали предметом зависти крестьян и чиновников. Высокие зарплаты офицеров и их привилегированное положение начали раздражать общество, которое чувствовало, что государство его недооценивает или даже игнорирует.

Корпус охраны пограничья (КОП), представлявший собой специальное военное формирование, финансируемое Министерством внутренних дел, попадало под действие положений о заработной плате государственных служащих и военных. Изначально это был акт 1923 года, в котором говорилось, что базовый оклад солдат исчисляется на основании введенной этим законом табели о рангах и должностных окладах. В 1934 г. вступили в силу положения нового распоряжения, значительно упростившего систему оплаты труда военнослужащих.

Положение о заработной плате военнослужащих носило общий характер, без учета специфики службы КОП. Подробные финансовые инструкции, касающиеся служебных надбавок, были изданы в виде приказов командира КОП и не анализировались историками. Цель статьи - напомнить принципы выделения надбавок к окладам, их размер и обстоятельства их выделения. Кроме того, в статье рассматриваются вопросы распределения компенсационных надбавок, размера и правил предоставления служебных, пограничных и функциональных надбавок. Все эти надбавки, помимо вознаграждения за тяготы службы на границе, имели еще одну функцию: они должны были сделать солдат КОП невосприимчивыми к взяточничеству, потому что плохо оплачиваемый солдат легко брал взятки со стороны контрабандистов или столь же легко мог поддаться агитации со стороны агентов Советского Союза.

Ключевые слова: Польша 1918-1939, история военного дела, Корпус Охраны Пограничья, оклады профессиональных солдат 